\title{
"A very interesting point in geography": The 1773 Phipps Expedition towards the North Pole
}

\author{
ANN SAVOURS (MRS. SHIRLEY)*
}

Fearless he stood, when frozen floods surround, And the strong ship in crystal chains was bound:When hope has dwindled to the smallest speck, And crowding ice has risen to the deck; The ship half coffin'd in the biting frost, And home and country seem for ever lost; Undaunted PHIPPS survey'd the frightful scene, With heart unconquer'd, and his mind serene.

(Winter's Harp of St Hilda) ${ }^{1}$

It is not surprising that the great eighteenth-century voyages of circumnavigation to Terra Australis and the South Seas have overshadowed the expedition of His Majesty's Ships Racehorse and Carcass to the Arctic in the summer of 1773. The results of the Pacific voyages were of immense importance to geography, science, politics, philosophy and art - as recent studies of Cook, Bougainville, and other navigators have shown. The same cannot be said of Phipps's voyage of 1773, since it discovered no new land or people, lasted only for one season, and did not attain the North Pole. It was, nevertheless, of considerable historical and scientific interest and deserves greater recognition than merely being known as the expedition on which young Nelson tried to shoot the polar bear. The voyage has sometimes been called a failure, but when one considers the matter, it was bound to fail. It was not until two centuries later, in our own time, that a ship navigated the ice of the central polar basin to reach the North Pole.

The polar route had been advocated as a way towards the riches of the Indies from the days of Robert Thorne, merchant of Bristol in the early sixteenth century and by the Muscovy Company and others in the seventeenth century. Voyages towards the north were made by Dutch and English ships, resulting in the discovery of Spitsbergen and the establishment of a profitable whaling industry by the Dutch, Danes, French, North Germans, and English. The seas north of $80^{\circ}$ remained unexplored, although retreating ice occasionally tempted whalers beyond $81^{\circ}$.

This unknown area on their globes was seen as something of a reproach to the Age of Enlightenment by a number of the voyagers and savants of the later eighteenth century. Among these was the Pacific explorer Louis-Antoine de Bougainville (1729-1811) in France, not long returned from his round-theworld voyage of 1766-69. Martin-Allanic (1964) in his admirable study of Bougainville writes that after completing his Voyage autour du monde, Bougainville in 1772 re-read the words of Maupertuis which stressed the need to solve the problem of the "Passage par le Nord", and the likelihood that there would be less ice in the open polar sea than near the land: ' "Si ce sont de vastes mers qui occupent les régions du pôle, on y trouvera moins de glaces que dans des lieux moins septentrionaux, où les mers seront resserrées par les terres: et la présence continuelle du soleil sur l'horizon pendant six mois, peut causer plus de chaleur que son peu d'élévation n'en fait perdre." Martin-Allanic describes Bougainville's contacts with the duc de Croy, grand seigneur and amateur of geography and science, who was also anxious to encourage the completion of the exploration of the globe. In the event, it was his fruitful collaboration with the young Jean-Dominique Cassini, assistant astronomer at the Académie Royale des Sciences that led to Bougainville's plan being considered at the request of Monsieur de Boynes, Ministre de la Marine and recommended by the Académie des Sciences for official approval. Bougainville thought that a North Polar expedition should be organized in two stages: the first year a reconnaissance in a single vessel to consult with the whalers at the ice edge, to observe the weather, currents, and sea ice, and to find a suitable site on Spitsbergen where scientific observations might be made. The following year (stage two) would see a bolder attempt to make the northern passage by one of two ships, while the other transported and afterwards remained near the observers and their apparatus at Spitsbergen. In his memorandum of 29 August 1772, Bougainville made precise recommendations for the building of a new vessel and for the reconditioning and adaptation of the Étoile, his old ship. He likewise asked for a certain complement of officers, men, and observers, as well as specific scientific instruments. However, because of a shortage of funds and of competition for them with Kerguelen's second voyage to the Terres Australes, Bougainville's project was refused by the Minister on 7 September 1772 and so came to nothing. ${ }^{2}$ Nevertheless, Bougainville did not lose interest in the possibility of navigation near the North Pole, and later in life, in 1801, as Citoyen Bougainville, his Essai historique sur les navigations anciennes et modernes dans les hautes latitudes septentrionales (Part one) was published. ${ }^{3}$ The published essay has a great literary quality, as is evident in the following paragraph in which he illustrates the difference between the soldier reaping glory in battle and the lonely navigator in uncharted seas. Bougainville had, of course, served as a soldier under Montcalm at Quebec.

*National Maritime Museum, Greenwich, London SE10 9NF, England 
Qu'a leur occasion il soit permis à un homme qui s'est essayé dans la carrière des découvertes, et qui a fait la guerre sur terre et sur mer, de comparer le courage du guerrier avec celui du marin voué aux découvertes. A la guerre tout anime et soutient, l'appareil, l'exemple, la foule des spectateurs; et pour un jour de dangers brillans, il en est cent de jouissances flatteuses à l'amour-propre. Enfin, si le guerrier périt, c'est au milieu des siens, et le laurier couronne l'urne où se déposera sa cendre. Mais le navigateur, cet isolé, c'est dans le plus vaste des déserts, entre le ciel et les flots, souvent ennemis, qu'il lui faut combattre des dangers tristes et sans cesse renaissans; c'est dans tous les instans dont se compose les jours, les mois, les années, qu'il lui faut un courage froid, une constance inaltérable; et, de plus, il sait que si, après une longue suite d'efforts couronnés par le succès, il périt à la fin peut-être de son entreprise, il n'en restera pas plus de traces que son vaisseau n'en laisse sur cette onde qu'il a sillonnée.

(Bougainville, 1801:54-55).

The precise connection between Bougainville and the 1773 British voyage towards the North Pole has not yet been found. The biographers of Bougainville, including Martin-Allanic (1964:1374,1387), state that when the Royal Society of London learned of the failure of his proposal, Bougainville was approached in the interests of science and as a Fellow of the Society, to transmit his plans to London. This he is said to have done and to have indicated two possible routes to the Pole, route $A$ and route $B$. The evidence for this statement rests on the footnote in Michaud's Biographie Universelle to the article on Bougainville "de qui nous tenons également ces détails" and on the oration at his death by the permanent secretary of the Académie des Sciences. As Martin-Allanic remarks, the archives of the Royal Society are silent on the subject, nor has anything yet been found in the Admiralty records. Phipps expressed his obligation to the philosopher d'Alembert ${ }^{4}$ and sent him a copy of his book, ${ }^{5}$ yet he did not thank Bougainville, either there or in the letter to him written after its publication. ${ }^{6}$ Neither did he at that time send Bougainville a copy of the Voyage, though he probably did later, on request. ${ }^{7}$ It seems out of character that Phipps should not acknowledge such a debt to the expedition. A French connection may be indicated by the fact that the French ambassador, the Comte de Guines, came on board the Racehorse and Carcass on their departure, although it must be said that he had also visited the Resolution and Adventure the previous year. A longer search in both French and English archives will doubtless reveal more.

\section{SAMUEL ENGEL}

The thinker behind the aims of the Phipps voyage appears to have been Samuel Engel, the Swiss geographer (1702-1784), whose writings were concerned in large part with the history of northern voyages and the possibility of navigating by a polar route to the Pacific. His first book is the one which concerns us here. It was called Mémoires et observations géo- graphiques et critiques sur la situation des pays septentrionaux d'Asie et d'Amérique d'après les relations les plus récentes and was published in Lausanne in 1765. An enlarged German edition followed in 1772, the contents of which were drawn to the attention of the Earl of Dartmouth, Secretary of State for the American colonies. The Prime Minister, Lord North, and the Earl of Sandwich, First Lord of the Admiralty, were doubtless. made aware of it too. ${ }^{8}$ Engel supposed that ice was formed only from fresh water, and therefore chiefly near the land, being concentrated at the mouths of great rivers. He believed that "une mer vaste et libre" (Engel, 1765:262) would be found in the far north, and he gave quite detailed instructions as to the organization and conduct of the first expedition to sail directly to the north, away from the land (Engel, 1765:261-264). The book is said to have caused something of a sensation in England and France and to have inspired the Royal Society to submit to the king a proposal for such a voyage (Michaud, 1815). The great lexicographer, Dr. Samuel Johnson, expressed what may have become fairly general opinion on the subject: "Talking of Phipps' voyage to the North Pole, Dr. Johnson observed, that it "was conjectured that our former navigators have kept too near land, and so have found the sea frozen far north, because the land hinders the free motion of the tide; but in the wide ocean, where the waves tumble at their full convenience it is imagined that the frost does not take effect"' (Chapman, 1970:318).

\section{THE ROYAL SOCIETY}

The Englishman most convinced of the possibility of navigation towards the Pole was the Honourable Daines Barrington (1727-1800), lawyer, naturalist, and antiquarian, ${ }^{9}$ who, like Engel, refused to be daunted by apparent proof of its impracticality (Fig. 1). He was elected a Vice President of the Royal Society on 10 December $1772 .^{10}$ On 19 January 1773, at a Royal Society Council meeting chaired by the President, Sir John Pringle, the following was minuted: ${ }^{10}$

The Hon. Daines Barrington having mentioned a conversation he had with Lord Sandwich about the practicability of a Navigation to the North Pole, and by it to the East Indies, the Council ordered the following letter to be written by the Secretary, and immediately sent to Lord Sandwich,

My Lord,

I am directed by the President and Council of the Royal Society, to represent to your Lordship, that they have lately had under consideration the probability of Navigation being practicable nearer the North Pole than has been generally imagined; and that there is room to hope, that a passage by or near the North Pole to the East Indies may be thereby found out. And as a voyage made towards the north-pole might be of service to the promotion of natural knowledge, the proper object of their institution, they cannot but be much interested in the prosecution of the same. They therefore beg leave to recommend it to your Lordship who have always shewn such readiness in promoting science and geographical knowledge, whether it might not be proper to take some steps towards the making such a discovery.

As a result of this letter, at about the beginning of February 


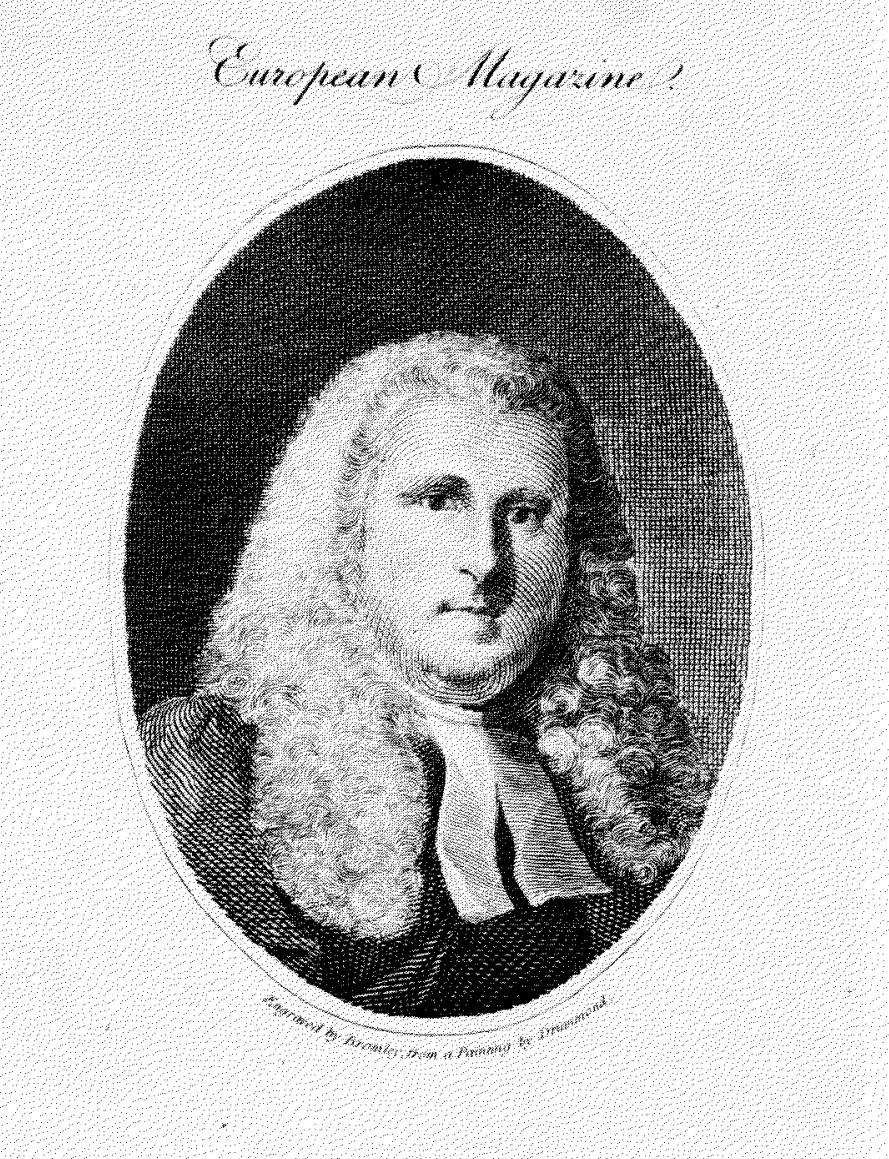

THE 110 N. DAINES BARINGTTON.

FG. 1 . Portrait of the Hon. Daines Barrington (1727-1800) from the European Magazine (1800), between pp. 278 and 279. Engraved by Bromley from a painting by Drummond.

Lord Sandwich laid before King George III a proposal for an expedition towards the North Pole. His Majesty was pleased to direct that this should be immediately undertaken, with every encouragement and assistance that could contribute towards its success (Phipps, 1774:10). Captain the Hon. Constantine John Phipps (1744-1792), on hearing of the design, offered himself and was entrusted with the conduct of the undertaking. He was appointed to H.M.Sloop Racehorse at Deptford on 19 April 1773; and Captain Skeffington Lutwidge (1737-1814), later Admiral of the Red, was appointed to H.M.Sloop Carcass at Sheerness:

\section{THE SHIPS}

Both these ships were bomb vesseis, stoutly built to withstand the recoil of heavy mortars. They were not overlarge and thus were well adapted "for navigating seas know to abound with shoals and covered rocks.... They were, besides, furnished with a double set of ice poles, anchors, cables, sails and rigging, to provide against the terrible effects of the severe and tempestuous weather that frequently happens in high latitudes"."
The Navy Board was told by the Admiralty of the projected voyage of the Racehorse and Carcass on 9 February 1773. Its members proposed in a letter of the next day "that the bottoms of the said sloops may be doubled; their bows fortified by breasthooks and sleepers, and additional ryders added in the space between the bomb beds." The Admiralty minuted on 13 February that the vessels should be fitted accordingly, the Racehorse at Deptford and the Carcass at Sheerness. ${ }^{12}$ The draughts showing the alterations for the voyage are still extant in the Admiralty collection of ships' plans in the National Maritime Museum (Figs. 2-5). The Racehorse had new chainpumps "made by Mr. Cole according to Captain Bentinck's improvements"' (Phipps, 1774:11). The boats were calculated to be able to transport the whole crew in case of loss of one or both ships. (Phipps, 1774:11). A store of bricks and mortar was also provided with which to build a retreat in case of being wrecked (Markham, 1879:97-99).

\section{VICTUALEING AND CLOTHING}

The anonymous author of the narrative quoted above, in praising Lord Sandwich for fitting out the expedition so well, tells us that his Lordship was no less careful to provide for the comfortable subsistence of the men.

His first care was, to issue orders for killing and curing a sufficient quantity of beef and pork in the best manner possible, that their provisions might be good and fresh; and his next, to cause one hundred buts of porter to be brewed with the best malt and hops, that they might have proper drink to fortify themselves against the rigour of the climate they were.about to pass. Their pease, oatmeal, rice and molossus, were all provided with equal care, and when all things were in readiness, the beer was stowed in the holds, and the vacancies filled up with coals, which served as ballast, that firing might not be wanting to warm and dry them when cold, or wet with labour, or with watching. Add to this, that a double quantity of spirits were put on board, with a large proportion of wine, vinegar, mustard, etc. etc., and what we believe; was never before thought of in the fitting out of any. King's ships, a considerable quantity of tea and sugar for the sick. ${ }^{13}$

Portable soup was also provided. A generous amount of flour for the baking of fresh bread (instead of ship's biscuit) was allowed, as well as "a larger allowance of suet and plumbs than usual". 14

In his journal of the voyage ${ }^{15}$ Phipps compares victualling "by the ordinary method"' with that of the Racehorse, one of the chief advantages of the latter being to give the men a hot breakfast and meat for dinner every day. ${ }^{16}$. Furthermore, "That nothing might be wanting towards preserving the health of the ship's company", wrote one of the midshipmen, "the famous Dr. Irving, as we believe, willingly undertook to go in quality of surgeon with us. Dr. Irving, in case it should not be remembered, was the gentleman who found means to reduce salt water to fresh, and who, besides his excellence as a surgeon is justly noted for his knowledge in Natural Philosophy" (Markham, 1879:99-100). Dr. Charles Irving (d. 1794), of whom we shall hear more, was also said to have "formed a project for preserving flesh meat fresh and sweet in long voyages, but it did not answer in this". 17 


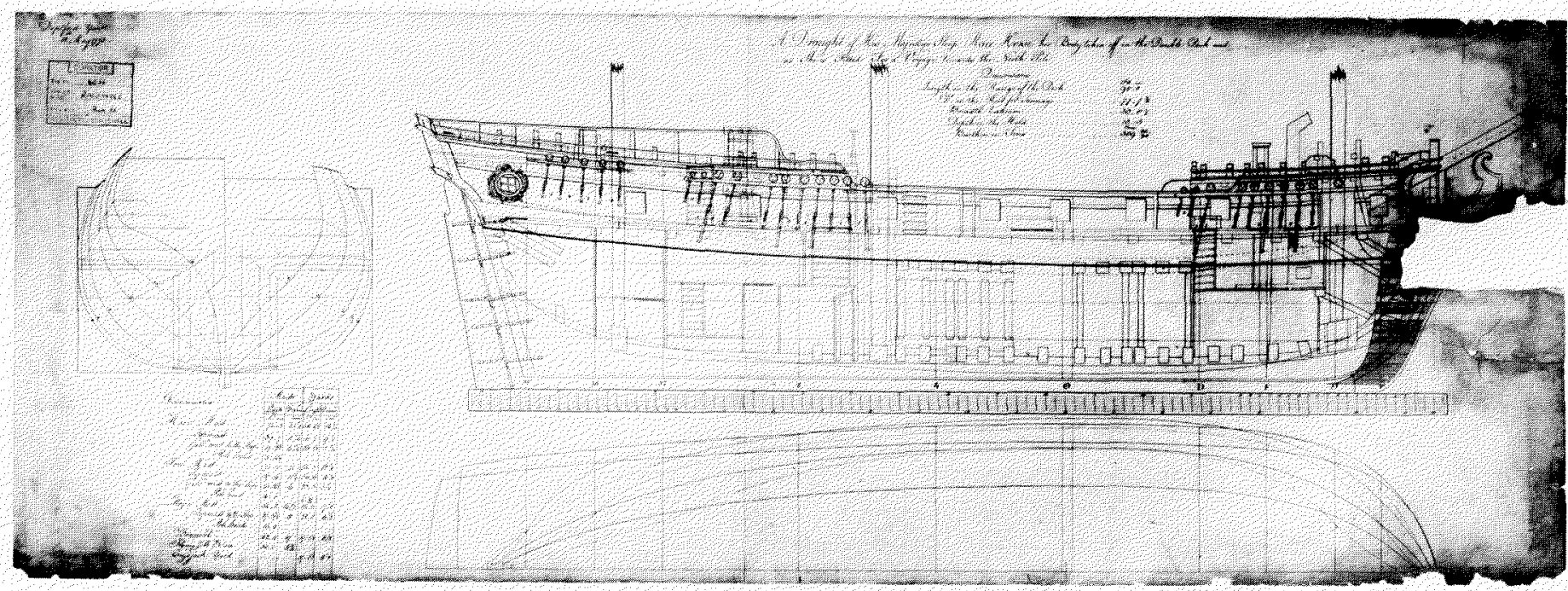

FIG. 2. "A draught of His Majesty's Sloop Race Horse ... as she is fitted for a voyage towards the North Pole... Deptford Yard, 18 May 1773". Original in the National Maritime Museum, Admiralty Draughts Collection, No. 6456. Size 14.5 x $39.5 \mathrm{in}$. (37 x $100 \mathrm{~cm}$ approx.). Reproduced by kind permission of the Trustees. A model has been made from this and other Admiralty plans (see Stewart-Blacker, P. 1980. HMS.Racehorse. Model Shipwright 33:2-6). The author says that she was French-built as the privateer Marquis de Vandrevil, captured 1757.

Nor was warm clothing forgotten. Each man was given two flannel jackets, cotton shirts, cotton handkerchiefs, two lined fearnought jackets, two lined inside waistcoats, two milled yarn caps, one pair of boots, two pairs of boot stockings, two pairs of fearnought trousers, and twelve pairs of mittens. ${ }^{18}$ Officers as well as men received this allocation. ${ }^{19}$

\section{CONSTANTINE JOHN PHIPPS (1744-1792)}

The Honourable Constantine John Phipps (Fig. 6), later Lord Mulgrave, was well suited to be the senior officer of what Conway (1906:283) has called "the first purely geographical Arctic expedition... in intention, a purely scientific mission...". He came from a lively and distinguished family and was at Eton with Joseph (later Sir Joseph) Banks, who accompanied Cook on his first voyage and who was president of the Royal Society for almost a lifetime. Phipps was born in 1744 and in January 1759 joined the Monmouth (60 guns) as a cadet under his uncle Augustus John Hervey. The Monmouth maintained constant watch on the French fleet for 21 weeks in 1759, perhaps the most famous of Hervey's exploits (Lysaght, 1971:60). Phipps remained with his uncle on the latter's ap-

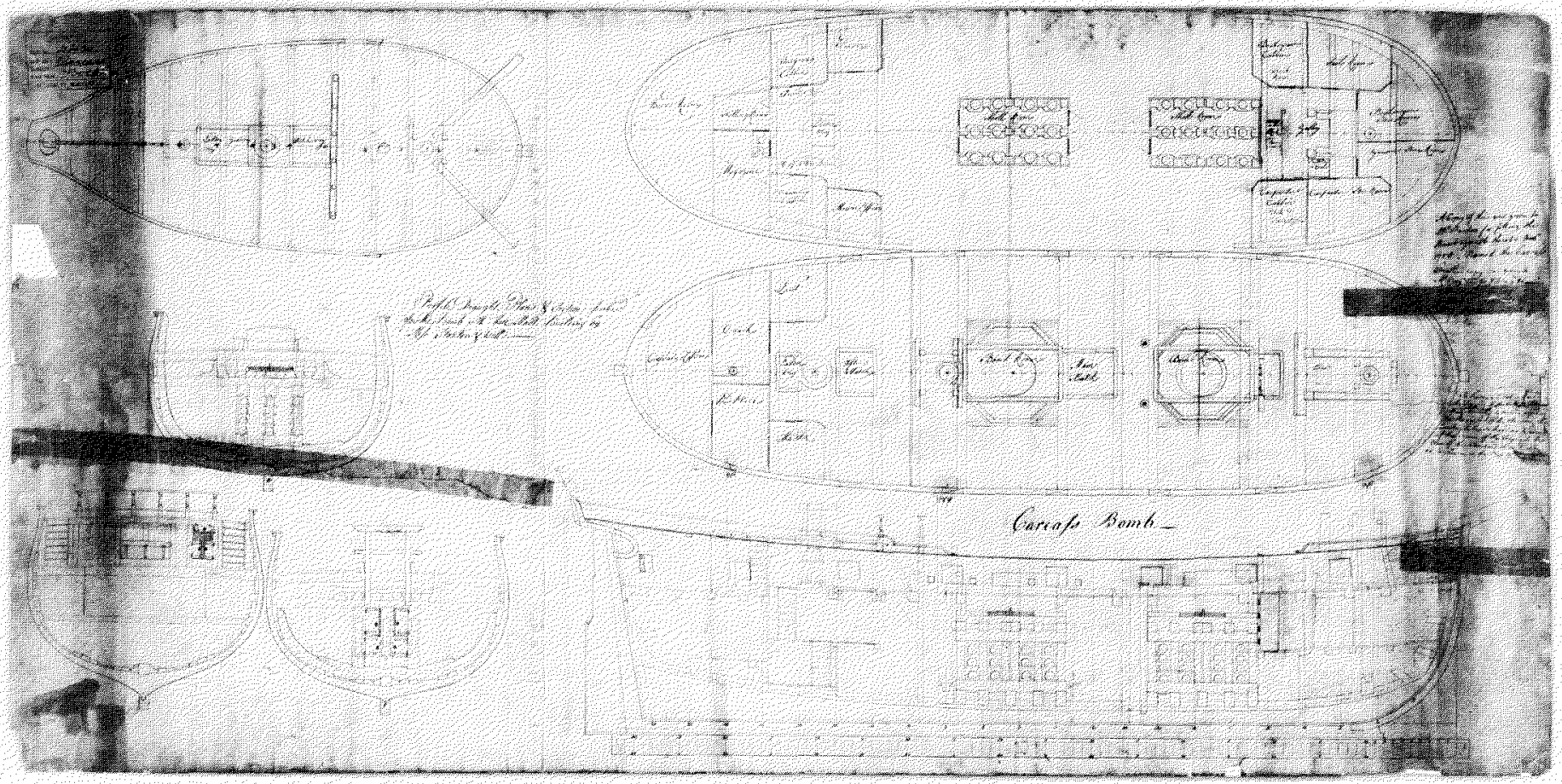

FíG. 3. "Protile draught, plans and sections proposed for the Bomb with three masts building by Messrs Stanton \& Wells. ... A copy of this was given to Mr Stanton for fitting the Bomb agreeable thereto, Novr. 1758, named the Carcass": Original in the National Maritime Museum, Admiralty Draughts Collection, No. 4420. Size $21 \times 42$ in. (53.5 $\times 105 \mathrm{~cm}$ approx.). Reproduced by kind permission of the Trustees. 


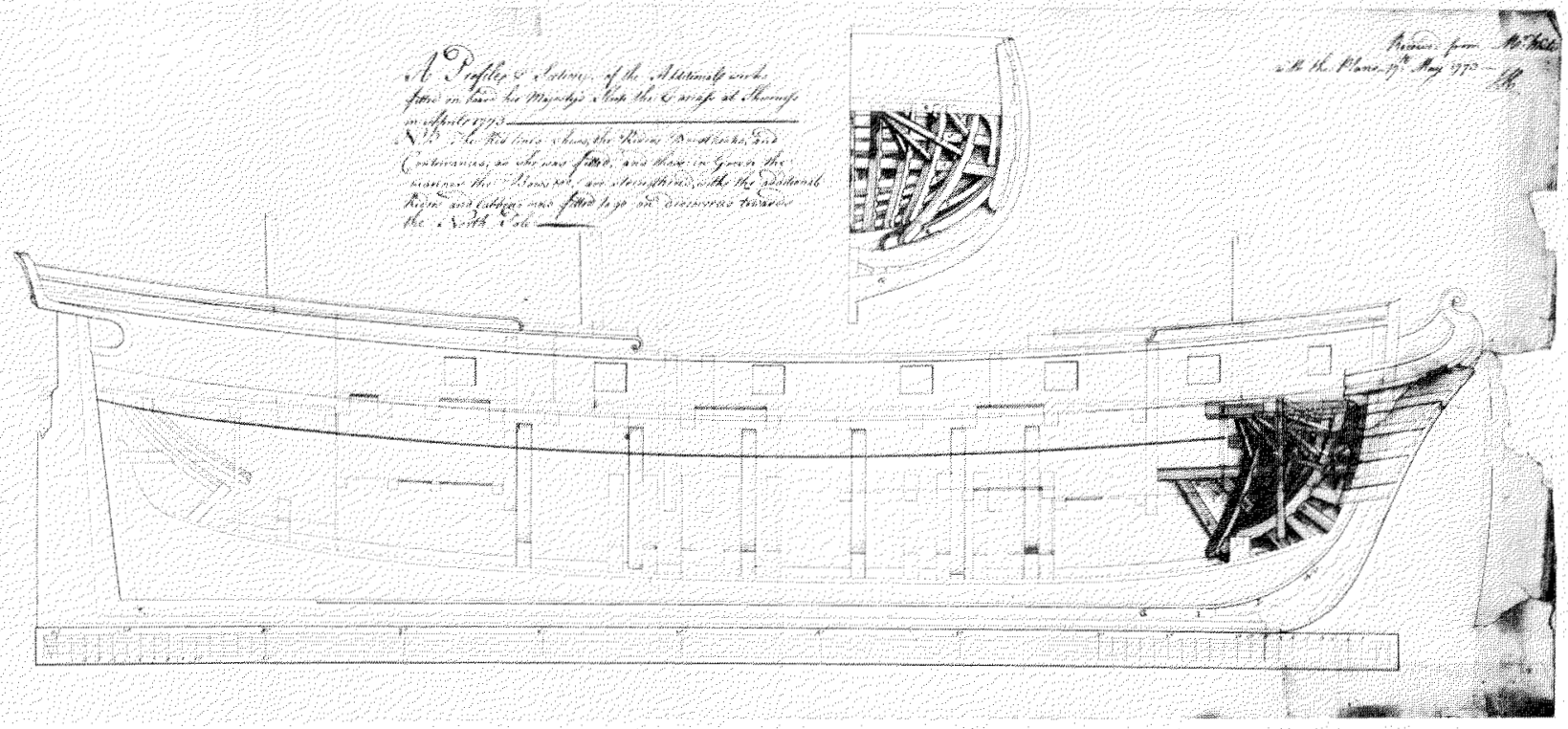

FIG. 4. "A profile and section of the additional works fitted on board His Majesty's. Sloop the Carcass at Sheerness in April 1773"'. Original in the National Maritime Museum, Admiralty Draughts Collection, No. 6359. Size 12.75 x 31.5 in. (32 x $80 \mathrm{~cm}$ approx.). Reproduced by kind permission of the Trustees.

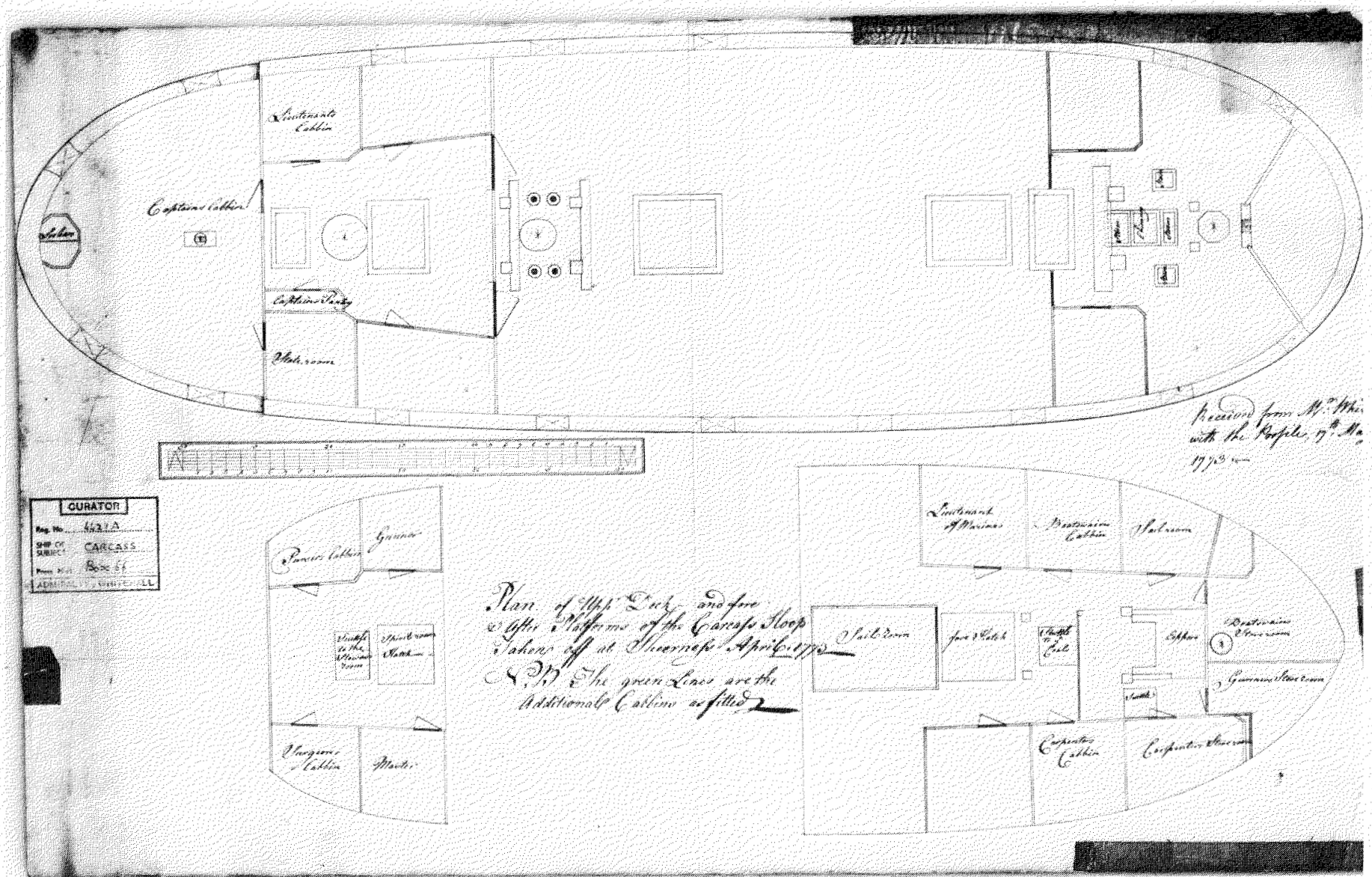

FIG. 5. "Plan of Upp. Deck and fore and after platform of the Carcass Sloop taken off at Sheerness April 1773. NB The green lines are the additional cabbins as fitted." Original in the National Maritime Museum, Admiralty Draughts Collection, No. $4421 \mathrm{~A}$. Size $14.5 \times 23$ in. (37 x $58.5 \mathrm{~cm}$ approx.). Reproduced by kind permission of the Trustees. 


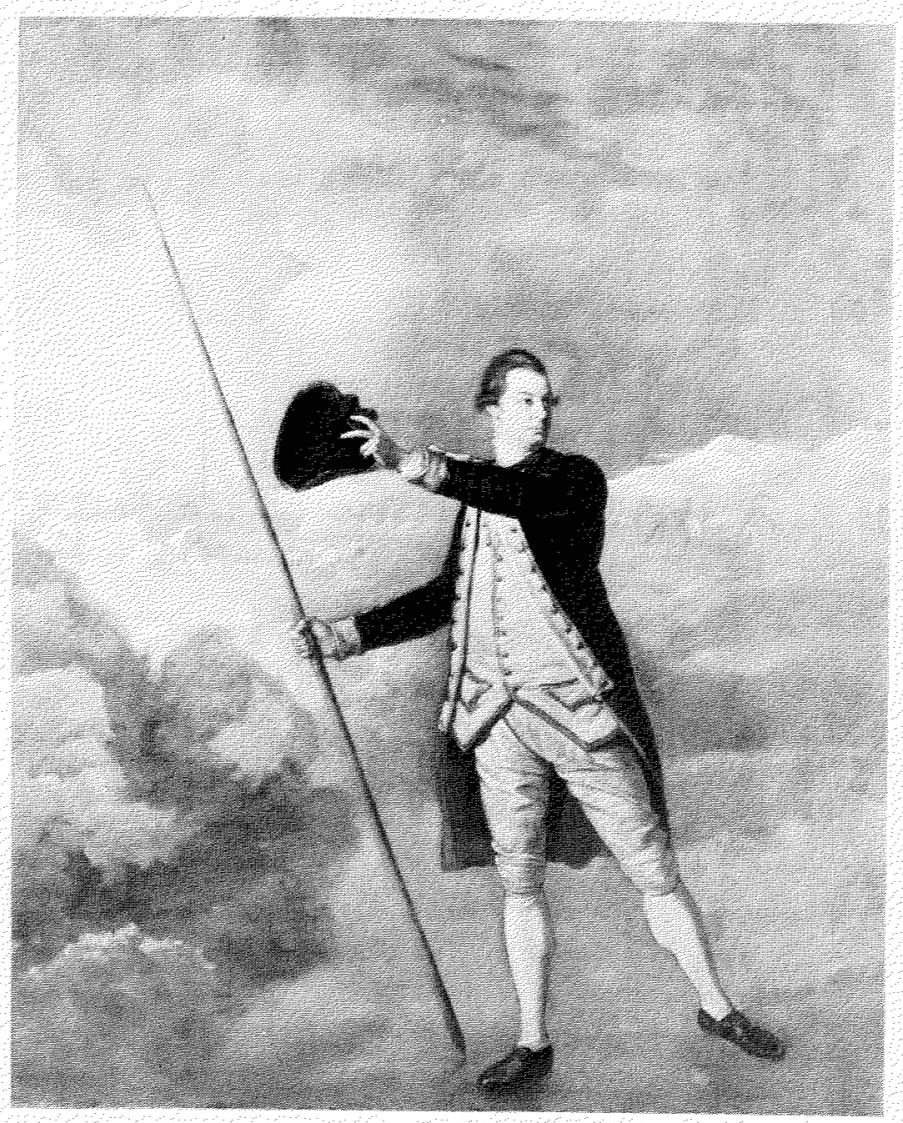

FIG. 6. Full-length portrait of Captain the Hon. Constantine John Phipps (1744-1792) seen before a background of ice over which sailors from the Racehorse and Carcass are hauling the boats. Oil. Attributed to Zoffany (1733-1810). National Portrait Gallery, London. Reproduced by kind permission of the Trustees.

pointment to the Dragon in 1761 and was present at the siege of Havana, the capture of which broke Spanish power in America (Lysaght, 1971:61). Phipps became a lieutenant in 1762 , serving in the Dragon, the Diligence (12 guns), the Terpsichore (26 guns), and the Boreas (25 guns), of which he was commander. In 1766 he appears to have obtained leaveof-absence to visit Newfoundland and Labrador with the young Joseph Banks (then aged 23) in the Niger. Dr. Lysaght has produced a fitting record of this scientific venture in her book Joseph Banks in Newfoundland and Labrador, 1766, during which were obtained "the first extensive and properly documented scientific collections from that region'" (Lysaght, 1971:9). Phipps continued his naval career, being at various times a Member of Parliament, a sea-officer and a Lord of the Admiralty. Dr. Lysaght (1971:62) tells us that "between his periods of active service, Phipps actively pursued the arts of peace. His library of nautical books was famous and considered to be the best in England; he was a Fellow of the Royal Society and also of the Society of Antiquaries of London.' He was known for his oratory in the House of Commons (Markham, 1879:108), and his letters in the Royal Society reveal a man of good humour, lively intellect, good physique, and humanity. For instance, on one occasion, from Mulgrave Hall in north Yorkshire, Phipps described himself to a correspondent in the south of England ${ }^{20}$ as being "now returned to my rustic regimen of a draught of ale with my dinner no wine no supper to bed at $1 / 2$ past ten and up early - If I wished to vegetate I believe here I might rival any of the oaks as this is certainly the most healthy climate in the world." The previous day he had spent nine hours walking amongst the hills, six before dinner and three after, accompanied by the old Bailiff, of above fourscore years, whose sound memory, best spirits, and excellent teeth would make him "pass for a very hearty man under sixty amongst you scurvy southern people". Because "interest" (i.e., a patron or political connection) was necessary for advancement in the eighteenth century, Phipps may have owed his appointment to the 1773 expedition not only to his scientific bent, but also to the influence of his uncle and Banks with Lord Sandwich.21

\section{GREENLAND PILOTS}

Neither Phipps nor Lutwidge (Fig. 7) had experience of ice navigation, which was not to be wondered at since the last naval voyage to the Arctic was in 1741-42 when H.M. Ships Furnace and Discovery had sailed from London in search of the Northwest Passage (Williams, 1962; Rich, 1960/1961). This lack was made good by taking two Greenland whalers in each ship as pilots. The Navy Board wrote to the Admiralty on 26 February 1773, some two weeks after being informed of the expedition, as follows:

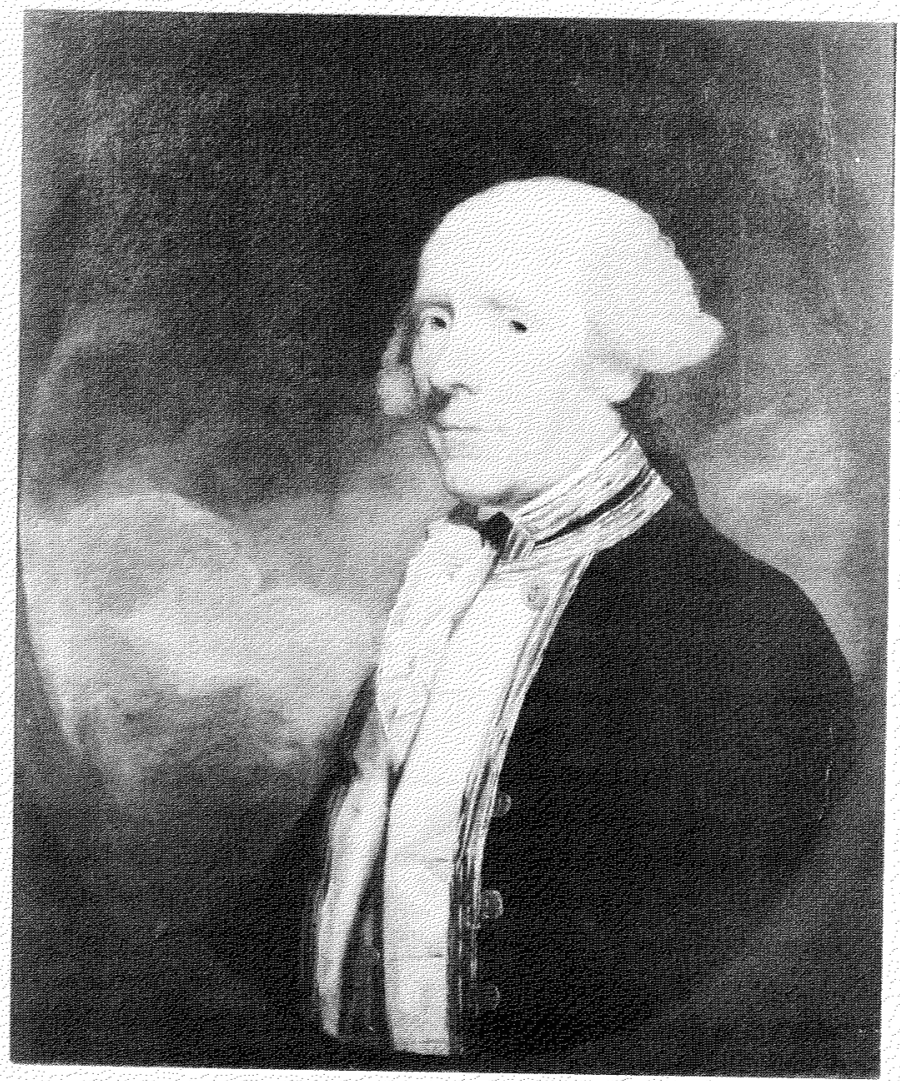

FIG. 7. Portrait of Admiral Skeffington Lutwidge (1737-1814) by Gilbert Stuart, painted in 1788. Oil. Believed to be in the Chrysler Museum, Norfolk, Virginia. 
... we beg leave to observe to their Lordships that we have not found any Masters in the Navy acquainted with the Greenland Seas, and therefore submit to their Lordships whether it may not be necessary to employ two persons on board each of the said vessels on their intended voyage in the capacity of extra pilots.

We believe such persons may be procured upon a certainty of being six months in employ if they are immediately engaged before the Greenland ships are fitted out, but when they are sailed, which will be shortly we apprehend they could not be had, and upon this account hereof, we desire you will propose to them that the Captains of the said sloops may be directed to enter and bear the persons that can be procured as extra pilots on the sloops' books to be paid at the rate of five shillings a day for the above time.

The Admiralty minuted on 3 March that four such persons should be engaged and borne on board the Carcass until the Racehorse was recommissioned. ${ }^{22}$ The Greenland whalers so engaged as extra pilots were Christopher Horner and Jonas English for the Racehorse; and Joshua Edwards and John Preston for the Carcass. ${ }^{23}$

\section{ADMIRALTY INSTRUCTIONS}

The first Instructions from the Admiralty to Phipps at Deptford and to Lutwidge at Sheerness are dated 16 April 1773. Phipps's set read as follows: ${ }^{24}$

Having appointed you Commander of His Majesty's Sloop Racehorse at Deptford which we have ordered to be fitted out at that place for a voyage towards the North Pole, mann'd with ninety men, according to the scheme on the other side hereof, victualled for six months with all species of provisions except beer of which she is to have as much as she can conveniently stow and brandy in lieu of the remainder, and to be stored in all respects proper for the said voyage; you are hereby required and directed to use the utmost despatch in getting the said sloop fitted, mann'd, victualled, and stored accordingly; and then sailing down to Galleons Reach take in her guns \& gunners stores at that place, and proceed to the Nore for farther order.

And as it is our intention that none but effective men shall serve on board the said sloop during her above mentioned voyage, you are to take care that no others be entered for her, we having given orders for the officers to be paid an allowance, by bill equal to the amount of the wages of the number of servants they are respectively entitled to. Given etc. 16 April 1773.

\section{Sandwich \\ Lisburne \\ A Hervey}

The complement to consist of:
1 Commander
3 Lieutenants
1 Master
1 Boatswain
1 Gunner
1 Carpenter
1 Purser
1 Surgeon
1 Surgeons Mate
1 Cook
3 Masters Mates
6 Midshipmen
1 Captains Clerk
2 Quarter Masters

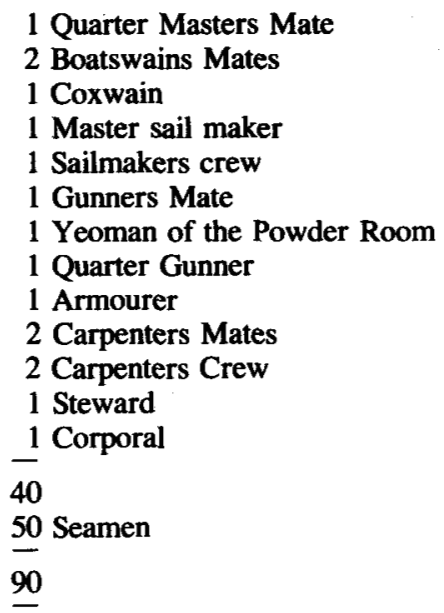

A list of officers in both the Racehorse and Carcass (complement 80 men) is given by A.H. Markham (1879:72-74). Further Instructions followed on 21 May concerning Mr. Israel Lyons (1739-1775), the Astronomer, who had been appointed by the Board of Longitude "to make nautical and astronomical observations and to make trial of some Longitude Watches." 25 Lyons was to be given convenient accommodation on board ship and to be afforded assistance and support in carrying out his Instructions, a copy of which was provided for Phipps. Whenever he wished to make observations on shore, he was to be furnished with a boat and enough men to help and if need be, to protect him, and in addition, sufficient "provisions and necessaries for his use". The remainder of the Instructions related to the "Watch Machines" to be sent out for trial under the care of Mr. Lyons. More will be said of these later.

Phipps received the following Instructions for proceeding with the Racehorse \& Carcass sloops to the North Pole from the Admiralty, dated 25 May $1773 .^{26}$

Whereas there is great probability that Navigation is practicable nearer the North Pole than has been yet ascertained and that by or near it, a passage to the East Indies may be found, though all the attempts which have hitherto been made from Europe have failed, owing to the [sic] having wasted too much of the season in coasting along shore and the obstructions thereby met with from the ice, instead of keeping more out to sea where obstructions of that kind are less likely to be expected; and whereas we are of opinion that a voyage made towards the said Pole, in order to ascertain how far navigation is practicable in that region, may tend greatly to facilitate any future attempt that may be made to discover a passage that way to the East Indies and cannot fail of being attended with many very interesting particulars in Geography and other branches of Science; and whereas we have, in obedience to His Majesty's commands, ordered the Racehorse sloop, whereof you are Commander, and the Carcass sloop commanded by Capt Lutwidge to be fitted out in a proper manner for such a voyage; you are hereby required and directed to fall down to the Nore in the first mentioned sloop, and there taking under your command the other sloop (whose Captain is directed to follow your orders) you are to make the best of your way with the said two sloops to the northward, and passing between Spitzbergen and Greenland, proceed up to the North Pole or as far towards it as you shall be able, carefully avoiding the errors of former navigators by keeping as much as possible in the open sea, and 
as nearly upon a meridian to the said Pole as the ice or other obstructions you may meet with will admit of.

If you arrive at the Pole and should even find the sea so open as to admit of a free navigation on the opposite meridian you are not to proceed any further, but, having made such observations there of every kind as may be useful to navigation or tend to the promotion of natural knowledge (which you are also to do during the whole course of your voyage) you are to return to the Nore exploring on your way back, how far navigation is practicable to the westward of the meridian of Spitzbergen as long as the season will admit of your doing so, without running any risque of losing your passage.

If you find it impracticable to proceed up to, or near the Pole, you are, in such case, and indeed in all events, to leave those seas so timely as to secure your return to the Nore before the winter sets in.

But, for as much as in an undertaking of this nature several emergencies may arise not to be foreseen and therefore not to be particularly provided for by Instructions beforehand, you are in such cases to proceed as you shall judge may be most advantageous to the service on which you are employed.

If any accident should happen to the Racehorse in the course of the voyage so as to disable her from proceeding any further, you are, in such case, to remove yourself and her crew into the Carcass and to prosecute your voyage in her, her Commander being hereby strictly required to receive you on board and to obey your orders the same in every respect as when you were on board the Racehorse; and in case of your inability by sickness or otherwise to carry these Instructions into execution you are to be careful to leave them with the next Officer in command who is hereby required to execute them in the best manner he can.

Upon your return to the Nore, you are to send to our Secretary an account of your arrival and proceedings.

Given etc. the 25th of May 1773.

Sandwich

Lisburne

A Hervey

Honble Capt Phipps

Racehorse Sloop in

Long reach

\section{BOARD OF LONGITUDE}

The Instructions to Israel Lyons, "appointed to go aboard one of the ships now fitting out for a voyage to the North-pole', were drafted by the Astronomer Royal, the Reverend Nevil Maskelyne (1732-1811), for the Board of Longitude and read to the Council of the Royal Society on 22 April 1773. The only comment to be minuted was to recommend to the Board of Longitude that Captain Phipps be empowered "to procure an Astronomical Quadrant, if possible to be had in time, for making observations on Land, if any opportunity of landing should be had"'.27 The Board of Longitude was a body set up at the time of Queen Anne in 1714 and abolished in 1828 , to consider inventions and methods, aimed at solving the problem of ascertaining longitude at sea. The sixteenth century had seen the beginning of scientific navigation, with instruments, charts, and nautical tables, plus means of latitude calculation and of plotting the ship's position. However, until the publication of the Nautical Almanac in 1767, there was no easy means of finding longitude (Gould, 1923; Howse, 1980). ${ }^{28}$ The method of "lunar distances", involving lengthy and complex calculations, was the only one that could be used until the invention of a reliable timekeeper or clock unaffected by the rolling of a ship, temperature, and pressure changes. Voyages to test a number of timekeepers or "watch machines" were made from France and England. The Board of Longitude's principal award of $£ 20,000$ (a huge sum, which illumines the importance of the problem) was nearly all granted over several decades to John Harrison (1693-1776), the Yorkshire clock maker and Copley medallist of the Royal Society. He was paid the first half $(£ 10,000)$ by October 1765 after the trials of his fourth timekeeper, now known as H4. Not until he was a very old man and the maker of a fifth watch machine, did he receive by Act of Parliament, through the King's intervention, a last major reward. ${ }^{29}$

Whether or not Harrison should be awarded the second half of the major prize had not been decided when Phipps left England. The final allocation to him of $£ 8,750$ was not agreed until 30 June 1773. Even after this, smaller rewards were given by the Board of Longitude for developments in the design of chronometers, as the timekeepers came to be called. The timekeepers of Mr. Arnold and Mr. Kendal (the latter [Fig.8] constructed on Mr. Harrison's principles) went out, therefore, under trial on board the Racehorse and Carcass, in competition presumably for the second part of the great prize. This

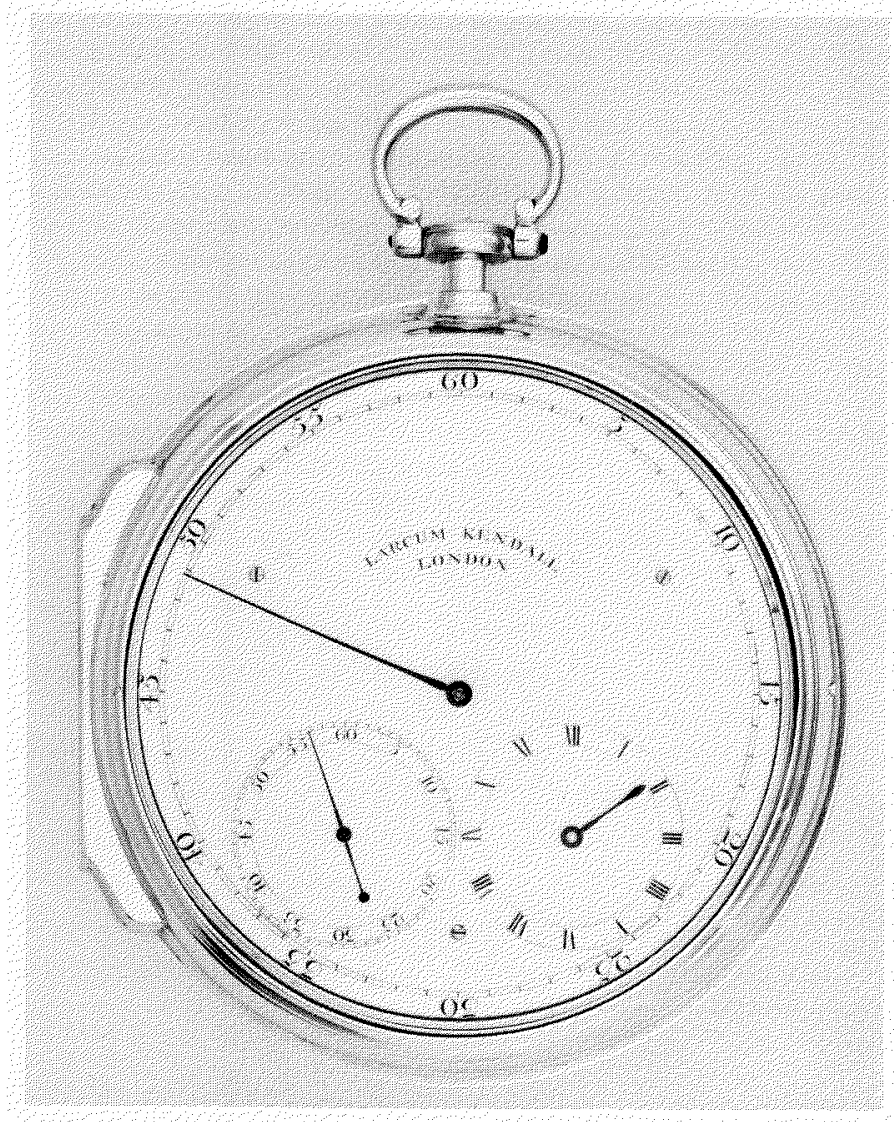

FIG. 8. The "Watch machine" (K2) by Larcum Kendal (constructed on Harrison's principles) taken to the Arctic in the Racehorse on trial, 1773. Later in the eighteenth century, it went to the South Seas with Captain Bligh of the Bounty and remained in the hands of the mutineers on Pitcairn Island until acquired by a Nantucket whaling captain. It was then transmitted via South America, through various hands, to the Admiralty and is now on display at the National Maritime Museum. 
accounts for the particular care with which they were to be treated, as set out in the Admiralty Instructions to Phipps of 21 May 1773. ${ }^{30}$ After specifying the manner in which Lyons, who was in charge of the timekeepers, should be received on board ship and landed on shore when he so desired during the voyage, the Instructions went on to state that whereas the Commissioners of Longitude

\begin{abstract}
.. . have thought fit that two Watch Machines (one made by $\mathrm{Mr}$ Larcum Kendal and the other by Mr John Arnold) should be sent out for trial in the said sloop under the care of Mr Lyons, and that another Watch Machine (made by the said Mr Arnold) should be sent out for trial in the Carcass, and have ordered three locks of different wards to be affixed to each of the boxes which contain the said watch machines as well as to prevent any improper management or ill treatment of them as to obviate any suspicions of mismanagement or ill treatment hereafter, and it being intended that yourself, your First Lieutenant and the above mentioned Mr Lyons, shall each have in charge one of three keys belonging to each of the boxes which are to be put on board the Racehorse and that the Commander, first and second Lieutenants of the Carcass shall each have in charge one of the keys belonging to the box which is to be put on board that sloop; you are to receive and distribute the several keys of the said boxes accordingly, and to be present yourself, and to see that your first Lieutenant be present every day when Mr Lyons winds up and compares the said two watch machines which are to be put on board the Racehorse, and to take care that the respective times shewn by such comparisons be properly inserted and attested under your respective hands in the general observation book, as directed by the above mentioned Instructions; and you are to give directions to the Commander of the Carcass to receive and take into custody the watch machine which is to be put on board that sloop and to wind the same up every day (in the manner directed by those Instructions) in the presence of his first and second Lieutenant, and to make such comparisons of the going of, and notations of the times shewn by the said watch machine as shall be judged necessary and practicable for the trial thereof, and to cause the same to be properly inserted and attested in like manner, in a book to be kept by him for that purpose; and you are to settle such signals with him as you shall judge necessary for obtaining daily information, if possible, of the times shewn by the watch machine under his care, in order that the same may be compared with the times respectively shewn by those on board the Racehorse.
\end{abstract}

In case of absence, Phipps was to deliver the keys to some other officer worthy of trust. He should instruct the Commander of the Carcass to do the same.

Israel Lyons the younger (1739-1775) was no stranger to the Board of Longitude. He had taught botany to Joseph Banks, had collected extensively for a flora of the Cambridge district, and had published a treatise on fluxions (1758). He was appointed one of the first four computers of the Nautical Almanac and Astronomical Ephemeris, in which his method for the correction of distance on account of reflection and parallax was used. ${ }^{31}$ The Instructions to Lyons himself, ${ }^{32}$ drawn up, as we have seen, by the Commissioners of Longitude, were transmitted on 24 April 1773. They related to the "nautical and astronomical observations" which he was to make, as well as to "other Services tending to the improvement of Geography and Navigation". A list of the instruments and books with which Lyons was entrusted was attached. The Instructions and schedule are transcribed in full as Appendix A at the end of this paper. The greater part (section 8 being where most variance occurs) echoes word for word those provided for the astronomers of Captain Cook's second and third circumnavigations (Beaglehole, 1955-1968: Appendices).

\section{BOUGUER'S LOG}

Another trial made during the voyage was of Bouguer's improvement of the common log, which Phipps found to be more accurate. In 1747 Pierre Bouguer improved the common log by counteracting the effect of wind and sea upon the surface of the $\log$ chip, and by overcoming the friction on the $\log$ reel which tended to cause the log chip to be dragged along with the ship. His log consisted of a cone of varnished wood to which was attached a metal sinker or weight sufficient to allow only the top of the cone to appear on the sea surface. The two parts were connected to each other by a line about 50 feet in length. The ordinary log line was attached to the cone and the whole was hove and used in the customary way. In 1753, Bouguer developed a $\log$ in which a globe was towed astern of the ship by a line. The other end of the line was attached to the end of a lever mounted in board. The pull of the line of the lever, acting against a spring attached to the lever, inclined it. The faster the ship moved through the water, the stronger the pull on the line and the greater the inclination of the lever, an angle which was indicated on a scale graduated for speed. The apparatus remained in use with some navigators for at least 50 years. ${ }^{33}$ Trial was also made of William Russell's and William Foxon's perpetual logs, about which Phipps (1774:97-98) wrote in the Appendix to his Voyage.

\section{JOSEPH BANKS}

Phipps received instructions from John Hunter ${ }^{34}$ and from Joseph Banks as to observations and collections in botany and zoology. He was requested to search for information on the migration of herrings and other fish, on the migration of birds breeding in high latitudes, and on the depredation of ship worms (Lysaght, 1971:256). He was also asked to collect whale foetuses from the whalers. The letter from Banks to Phipps of May $1775^{35}$ gave instructions on the drying of plants and on observations concerning the White Bear, "seels", whale foetuses, birds, fish, "blubbers", shells, seaweeds, insects, mosses, lichens, other plants, and the trunks of drifted trees. Mr. Banks's assistance and his long friendship with Phipps are recorded in the Introduction to Phipps's Voyage.

The previous year, Joseph Banks had intended again to accompany Cook on his second voyage in the Resolution and Adventure (1772-1775). However, as is well known, he refused to sail in the accommodation available and went to Scotland and Iceland instead. In February and March 1773 he made a visit to Holland with the Hon. Charles Greville. His biographer, Edward Smith, states that in Rotterdam Banks attended a meeting of the Batavian Society, at which he expressed the wish to undertake a voyage to the North Pole. He is said to have asked the members to communicate with him on the discoveries and observations that the Dutch nation had already made as far as $84^{\circ} \mathrm{N}$ and promised, in return, to fur- 
nish them with ample information concerning the results of his voyage (Smith, 1911:36). ${ }^{36}$ A Kentish newspaper ${ }^{37}$ informed its readers that a letter from the Hague of 2 March, received in London, reported that "some Englishmen, and among them the Sieur Banks, already well known for his voyages, will sail this year directly towards the pole"'. There seems to have been little truth in these assertions, according to Banks's Journal of a trip to Holland. ${ }^{38}$ The transcript of this journal, dated 1773, says no such thing. The entry for 10 March 1773 at The Hague reads as follows:

This morn I had a Levee of Groenland Captains, who had been sent for from Rotterdam, in order to give me such information as they might be able, which might forward Captn. Phipp's plan of sailing towards the Pole, which he is at present engaged in: from them I learned that they had all been to the NE extremity of Spitzbergen, or near it: that there they met with a current running to the Westward and Southward, withall which after having passed by Spitzbergen, kept away much more Southerly, appearing to keep along the Shore of Greenland: that they also in coming out had a current along the west side of Spitzbergen, running to the northward, which however extended but a little way from the Coast: one man said that he had been attempting to break into the Solid Ice between Spitzbergen \& Greenland but found it impossible: another said that he had been to the northward of the NE Island in Lat $81 \&$ had there a Sea to the Northward of him, quite clear of Ice: his compass he said was very unsteady, often pointing from the North: the waygats or passage between the main of Spitsbergen, $\&$ the NE Island, has generaly a Stream of wind blowing through it, which will put a Ship past almost all her Sails: while another lying not a mile from her, under either of the Headlands, will be quite becalmed: in the Lat of 75 they said that Ice was always met with in the fair way between Spitsbergen \& Greenland, which they imagined ran off like a point from the shore: \& probably marked the outlet of some fresh river; off the extreme point of this Ice they had soundings from 80 to 100 fathoms.

Banks also obtained advice from one Thomas Falconer, presumably the classical scholar (1738-1792), about other scientific work to be performed by the expedition. In a letter to Banks of 17 May $1773,{ }^{39}$ Falconer suggested studying the density of salt water and wrote: "This question includes much. The general idea now is that the sea water at the Poles contains much less salt, or in other words, is specifically lighter than that at the Equator. I know the experiment is rather difficult to ascertain \& may be more so at the pole $\&$ where the action of gravity may possibly be different. However, it may and should be tried first in these seas." He goes on to speak of other matters, including the provision of a hydrostatic balance for experimental purposes. It has been seen that one was provided for Lyons, presumably on Falconer's recommendation. As an afterthought, he hoped that Mr. Harrison's clock would accompany the voyage, "or at least that some experimnts will be made on the contraction of metals". Although the Instructions to Phipps from the Admiralty and from Banks, and those to Lyons from the Board of Longitude are to be found, those of the Royal Society itself have not, so far, come to light. At the Council meeting of 29 April 1773, the following was minuted:40
Papers of Mr Mountaine, the Hon Mr Cavendish, Mr Horsley, the Astronomer Royal and the Secretary containing Instructions and directions for the use of the observers that are to go on the expedition to the $\mathrm{N}$ pole were read; and it was desired of them that they would be pleased to permit the originals of their respective papers to be kept with the minutes of the Society and ordered that copies of them be made and delivered to Captain Phipps.

These documents are no longer with the series, nor do they appear to survive in the Mulgrave collection.

\section{THE VOYAGE}

On 21 May 1773, the Racehorse, being manned and rigged, dropped down the Thames from Deptford to Galleons Reach, where eight sixpounders and all the gunners' stores were loaded. Lord Sandwich came on board as "the last mark of the obliging attention he had shown during the whole progress of the equipment...to satisfy himself that the whole had been compleated to the wish of those who were embarked in the expedition''(Phipps, 1774:19). ${ }^{41}$ The French ambassador accompanied him and visited the Carcass at Sheerness on the same day. ${ }^{42}$ On 23 May, Phipps applied to their Lordships to take with him one of the boys from the Royal Mathematical School, Christ's Hospital. ${ }^{43}$ This was approved and James Robinson, clerk on board the Carcass, was sent. He is mentioned later in connection with the observations.

On 30 May the Carcass (Captain Lutwidge) joined the Racehorse at the Nore. On 2 June, Mr. Arnold came on board the Carcass to regulate the timekeeper, which had stopped "for want of being sufficiently wound up". ${ }^{44}$ Easterly winds prevented the ships from weighing anchor until 4 June. They then made their way towards the north, comparing longitude by the watch and by observation, dead reckoning by the common log and by Bouguer's log, and (wrote Phipps, 20 June) making "soundings at much greater depths than I believe had ever been attempted before, reaching 780 fathoms in the latitude of Iceland without getting ground on 20 June''(Phipps, 1774:27). The temperature of the water at that depth was measured by a thermometer invented by Lord Charles Cavendish. Phipps suspected, however, that his Cavendish thermometer, although compensated for pressure, was giving a false reading. He and Irving (the surgeon of the Racehorse) therefore intelligently tried to check by employing a quite different method: hauling water up insulated and testing it on deck. This was the purpose of the Irving bottle (Fig. 9). But the results were so much at variance that Phipps did not know which to believe, and with hindsight, we realize that his thermometer was insufficiently compensated for pressure (Cavendish's son had provided a table of corrections) while the bottle, having only one opening, would not capture a truly representative sample nor bring it back to the surface undiluted or unchanged by temperature. Insulation dependent on trapped air (as in wool) is useless at depth. ${ }^{45}$

The same day, Doctor Irving's apparatus for distilling fresh water from the sea (Fig. 10) was first used. It was found, on repeated trials, to be most satisfactory: "the water produced from it was perfectly free from salt and wholesome, being 


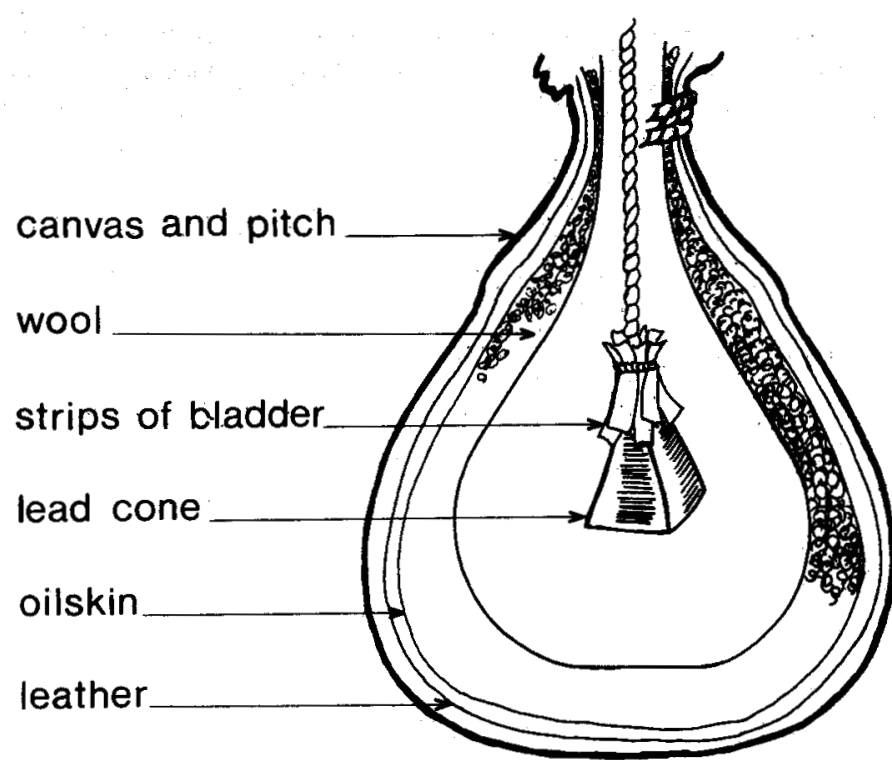

FIG. 9. Suggested form of Dr. Irving's water bottle for collecting deep sea samples, based on the description given by Phipps (1774:144). It was an interesting but ineffective idea, since all insulating material dependent on contained air will fail under deep sea pressure conditions. Reproduced by kind permission from the doctoral thesis of Dr. Anita McConnell.

used for boiling the ship's provisions" (salt beef and pork), "which convenience," wrote Phipps (1774:28) "would alone be a desirable object in all voyages, independent of the benefit of so useful a resource in case of distress for water... The quantity was generally from thirty four to forty gallons, without any great addition of fuel," more than adequate for each man. Letters were sent home on 21 June from latitude $68^{\circ} 05^{\prime} \mathrm{N}$ by a sealing vessel bound for Hamburg. By this vessel also returned home a Mr. Wyndham, "gentleman of fortune... unable to endure the seasickness". ${ }^{46} \mathrm{He}$ is not on the ships' muster rolls. On the $23 \mathrm{rd}$, when to the northward of $72^{\circ}$, a piece of driftwood and a small bird were seen. This must have been the Mealy Redpoll (Carduelis flammea flammea, Linnaeus) (Fig. 11), drawn by one of the midshipmen, Philippe d'Auvergne, (1745-1816), later the last Duc de Bouillon (Balleine, 1973). He is said to have "made all the sketches that were taken during the voyage and afterwards engraved; he was also charged with the meteorological register". 47 The temperature of the air, variation, and magnetic dip continued to be observed.

On 28 June, Spitsbergen (Fig. 12) was sighted, and on the 29th they stood close in to Prince Charles Island, whose coast, wrote Phipps, "appeared to be neither habitable nor accessible; it was formed by high, barren, black rocks, without the least mark of vegetation; in many places bare and pointed, in other parts covered with snow, appearing even above the clouds: the vallies between the high cliffs were filled with snow or ice. This prospect would have suggested the idea of perpetual winter, had not the mildness of the weather, the smooth water, bright sunshine, and constant daylight, given a chearfulness and novelty to the whole of this smiling and romantick scene". Although perhaps not needed on a day such as this one, warm clothing had been issued on $18 \mathrm{June}$, not only to the sailors, who joked that they were going to the North Pole "to cut a piece of it to make a walking stick for the Prince of Wales", ${ }^{48}$ but to the whole ship's company.

The Racehorse and Carcass continued to ply to the northward, sounding, observing, and surveying off the west coast of Spitsbergen. The master of a Greenland ship came on board during the evening of $\mathbf{3 0}$ June. He told them that he had just come out of the ice to westward and that two English and one Dutch ship had so far been lost. On 2 July, five sail of Greenlandmen were in sight. These would have been part of the whaling fleets of England, Denmark, Hamburg, or the Netherlands (Fig. 13). The English and Dutch (often with Basque harpooners) had first sailed to the Arctic in search of the right

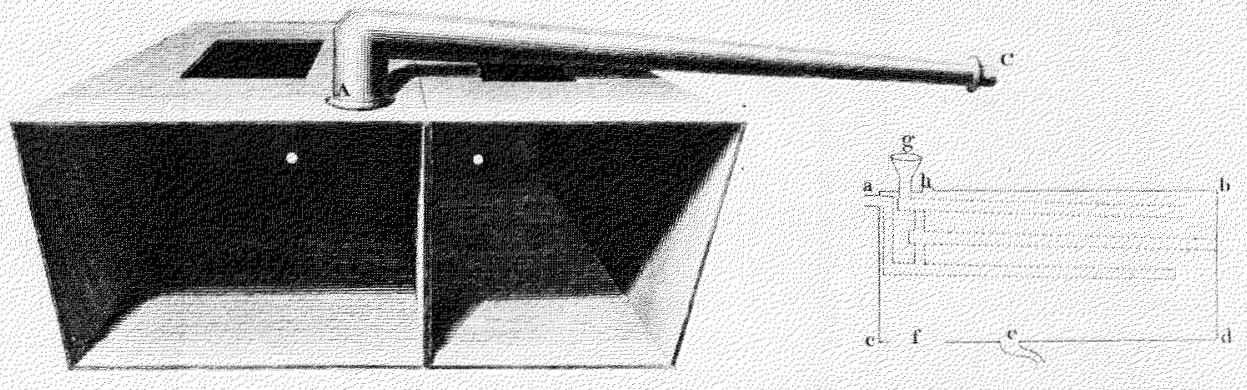

FIG. 10. Dr. Irving's apparatus for distilling fresh water from sea water. Plate from Phipps (1774: facing p. 222). 


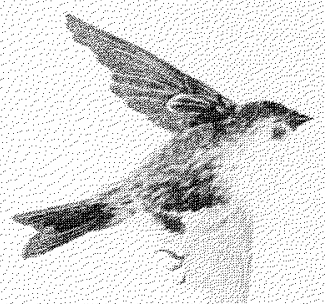

FIG. 11. Wash drawing by Philippe d'Auvergne (1754-1816), midshipman of the Carcass, of the Mealy Redpoll (Carduelis flammea flammea) that flew aboard the ships at $72^{\circ} \mathrm{N}$. It appears to be one of the few of his expedition sketches that has survived. The original is in the British Museum, London, Department of Prints and Drawings, Banks Collection. Reproduced by kind permission of the Trustees.

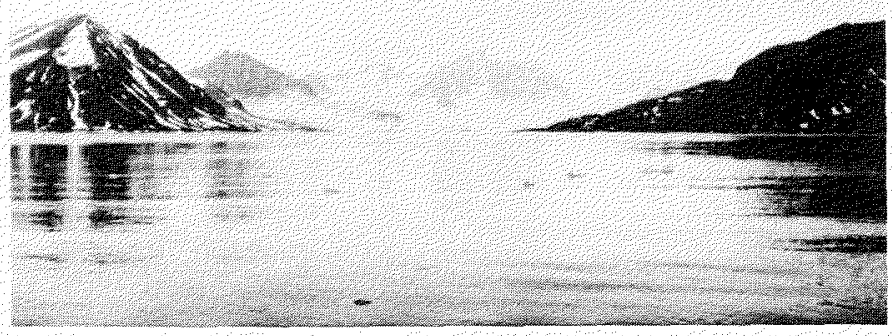

FIG. 12. View of Smeerenburgfjorden, Spitsbergen. Photo: Dr. M.J. Hambrey, courtesy of Cambridge Spitsbergen Expedition (SP 808).

whale (Balaena mysticetus) in the early seventeenth century. Whereas the Dutch industry continued largely to prosper, that of the English declined in the later seventeenth century, but revived in the middle of the eighteenth, partly owing to the market and partly because of Government bounties. Lubbock (1955 [1937]:114) tells us that in 1773, England sent 65 whalers and Scotland nine to the Arctic. ${ }^{49}$

On 4. July the Racehorse anchored in a small bay south of Magdalena Hook which is pictured in Phipps's narrative. The boat was sent to shore for water and the two captains also landed with the astronomer and his instruments, to observe the variation, but thick fog came down before these were completed. Lutwidge describes the land as being "barren, rocky, mountainous, and almost covered with snow". He noted "a quantity of driftwood on the Beach and near it, above high water mark". 50 The two ships joined company again; the
Racehorse firing guns in the fog. Phipps had earlier (17 June) given instructions to Captain Lutwidge as to signals to be observed in fog and had also given him a memorandum as to what course to follow in case the ships were separated, together with a packet to be opened in the event of final separation. On leaving any of the places of rendezvous, he was to "erect some conspicuous mark" and leave a letter informing Phipps of his departure. Lutwidge noted these instructions in his $\log .^{51}$

The Rockingham, ${ }^{52}$ a Greenland ship, ran under the Racehorse's stern in the early morning of 5 July (4 July ship time), giving news of the state of the ice off. Hakluyt's Headland, the northwest point of Spitsbergen. Her master presented the commanders with a deer and a half each, which they found well-flavoured. ${ }^{53}$ There are reindeer on Spitsbergen still. Phipps took the opportunity to write a brief letter to Banks (Lysaght, 1971:61-62), as follows:

\begin{abstract}
My dear Banks,
I am in $79^{\circ} 30^{\prime}$ \& have not seen a single bit of ice \& have been these three days without any fire and have no one day had a fire all day - have got you two small Blubbers - a Seal's Bill of: Fare out of his Belly containing sundry non-descript: Crabs \& other things several birds stuffed amongst them non descripts particularly a Larus Rissa with only 8 Remiges. Primores tho' Linnaeus attributes 10 you know to all Birds a Larus Niveus a Beautiful Bird etc etc. Remember me to Solander \& believe me most sincerely.
\end{abstract}

\section{Yours CJ Phipps}

Irvine is well \& would probably have said something had he been up it is now 4 o'clock in the morning \& the wind fair. Racehorse off Spitsbergen lat. $79^{\circ} 30^{\prime}$ ' July 4 th

Sir Martin Conway (1906:283) counts the discovery of Phipps's Larus niveus, the beautiful Ivory Gull (Pagophila eburnea Phipps), "the fairest bird of the Arctic regions" among the achievements of the expedition.

Phipps was also incidentally the first to give an adequate description of the polar bear (Thalarctos maritimus Phipps) and to give it a scientific binomial (Lysaght, 1971:62).

On 5 July; ice was encountered to the northwest of Dane's Gat and an attempt was made on the 6th or 7 th to get further to the north. A southwesterly wind on the 9 th enabled them to stand to the westward as far as Long. $02^{\circ} 02^{\prime} \mathrm{E}$. At 4:00 p.m. the same day they were in Lat. $80^{\circ} 36 \mathrm{~N}$ (the most northerly point ascertained by observation). No opening in the ice was seen, and the Carcass was lost twice in the night. The tiring work of making short tacks and using boats, ice anchors, and poles amongst the ice (Fig. 14) in wet weather, made them appreciate their warm clothes and extra allowance of spirits (Phipps, 1774:41). ${ }^{54}$ By the 10th, Phipps (1774:42) was of the opinion "that the ice was one compact impenetrable: body, having run along it from East to West above ten degrees". He determined to stand over the eastward; to see whether the body of ice joined onto Spitsbergen.

Further advance being impossible, they ran into Fair Haven, the roadstead at the northwest point of Spitsbergen between Hakluyt's Headland and a knot of islands, among them Cloven 


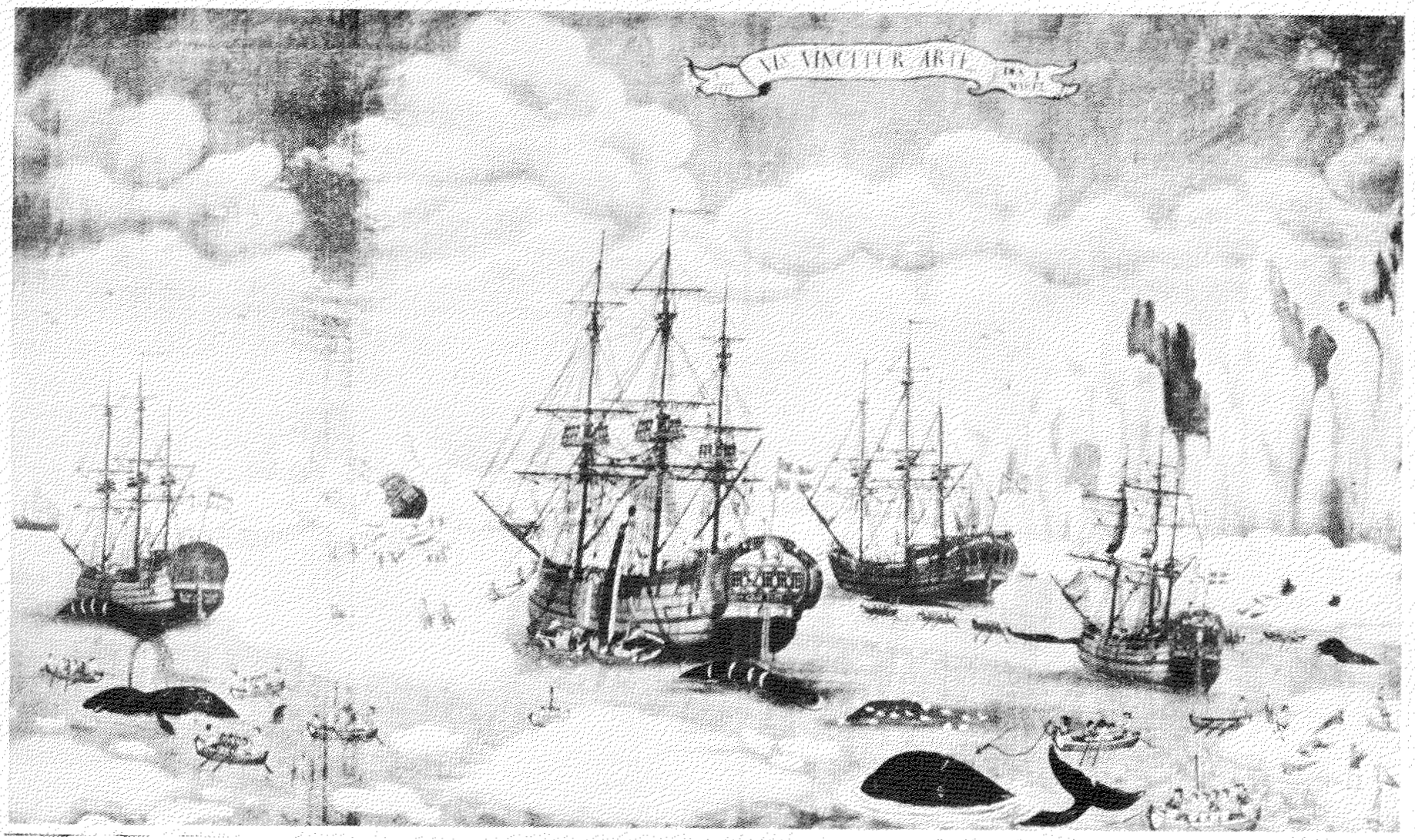

FIG. 13. The Graf Tott and other Danish, Dutch, and English whalers in Spitsbergen, 1777. From Bjarne Aagaard's Den gamle hvalfangst (Oslo, 1933).

Cliff, Vogel Sang, and the Outer Norway. They anchored here between 13 and 18 July, making survey, pendulum, and other observations. The two observation tents were set up on a "small flat island or rock, about three miles from the ship" (Phipps, 1774:45), which Conway (1906:279) calls Deadman's Island, but which Newbery's anonymous narrator calls Marble Island. ${ }^{55}$ The latter also says that the whaling captains often visited the observers and "expressed their admiration, not only at the perfection of the instruments, but likewise at the dexterity with which they were accommodated."

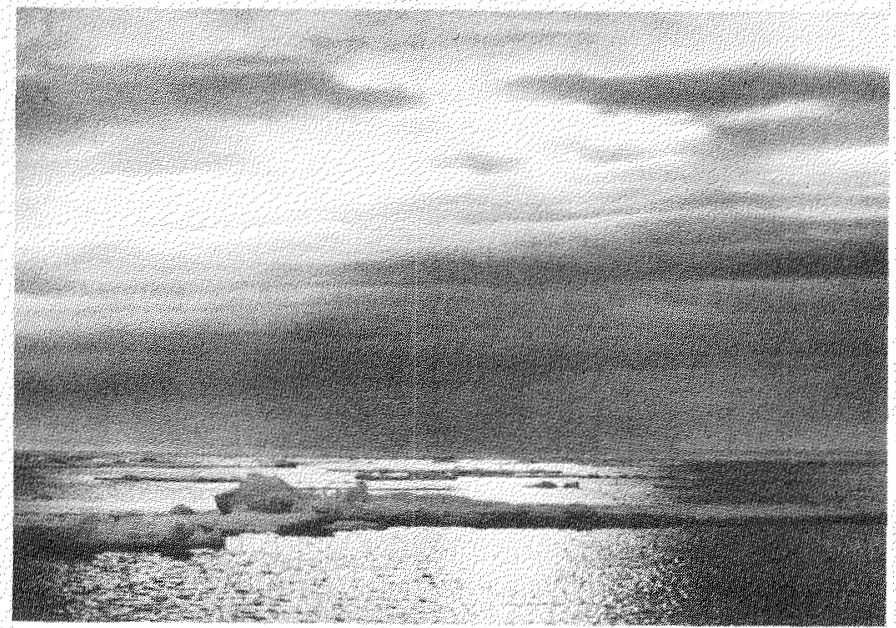

FIG. 14. View of loose pack ice off Spitsbergen. Photo: Dr. M.J. Hambrey, courtesy of Cambridge Spitsbergen Expedition (SP 200).
Thomas Floyd, one of the midshipmen of the Racehorse describes how Dr. Irving carried a barometer up the highest hill in the sound, finding its height to be 1240 feet. He was followed to the top by a black dog which barked at him all the time (Markham, 1879:152). Some surveying was done and a "wonderful chart was produced, which is still the marvel of those who take an interest in Spitsbergen surveying for its extraordinary badness" (Conway, 1906:279). ${ }^{56}$ For the actual chart drawn by Philippe d'Auvergne, the track chart to and from England, and for the more detailed track chart of July and August, see Phipps's Voyage (Fig. 15). ${ }^{57}$

While the scientific work proceeded, some of the men took in water, some went hunting, some handed the sails and spread them out to dry, and others scrubbed the ships or viewed the country. ${ }^{58}$ They found this to be stony and full of mountains, precipices, and rocks, with "ice hills" (i.e. glaciers) or the ice cap in between these. The mountains seemed to assume "a thousand different shapes of trees, castles, churches, ruins, ships, whales, monsters, and all the various forms that fill the universe." 59 Sometimes the sun created a prospect of inconceivable brilliance by shining upon the ice hills, which "put on the bright glow of the evening rays of the setting sun, when reflected upon glass, at his going down; sometimes they appeared of a bright blue, like sapphire, and sometimes like the variable colours of a prism, exceeding in lustre the richest gems in the world, disposed in shapes wonderful to behold, all glittering with a lustre that dazzles the eye, and fills the air with astonishing brightness". ${ }^{60}$ The anonymous "journalist" 


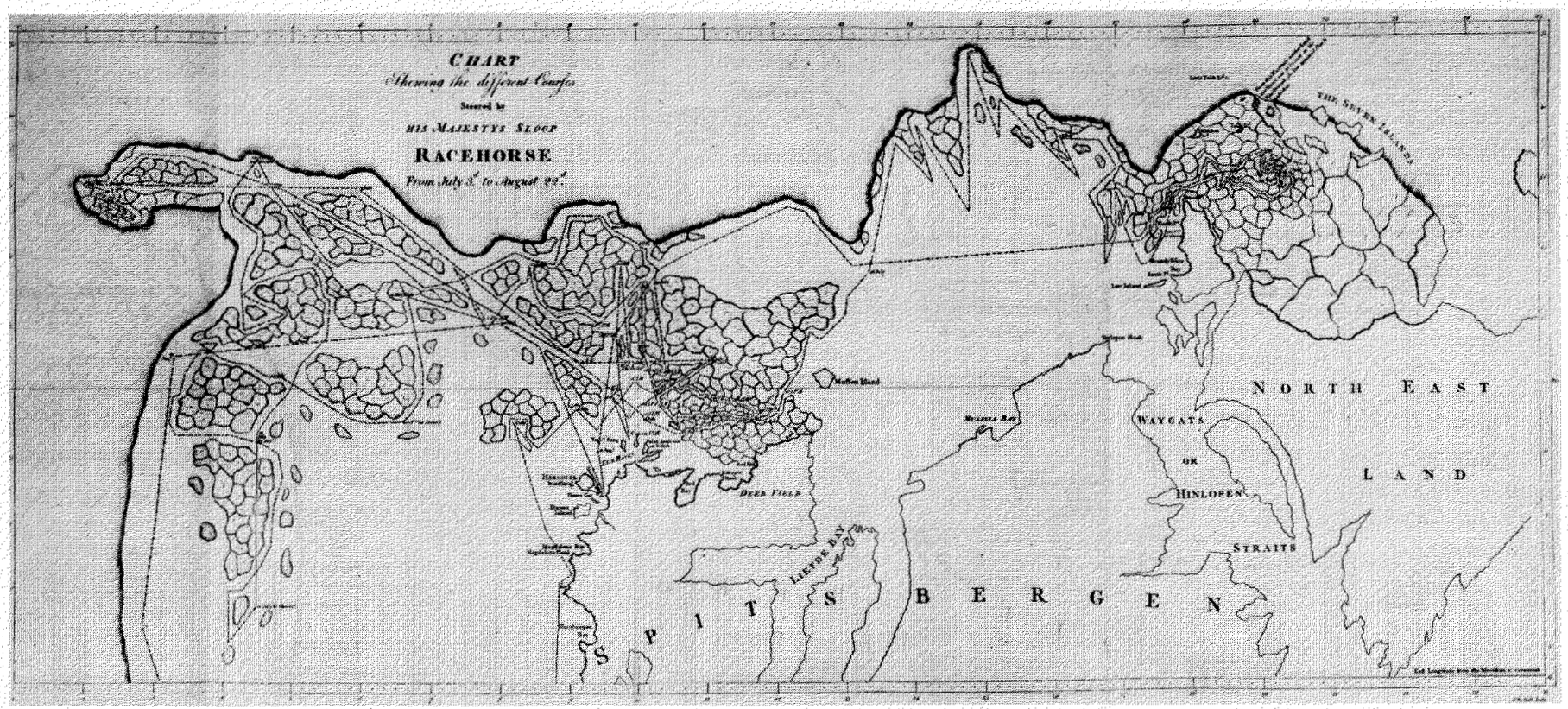

FIG. 15. "Chart showing the different courses steered by His Majesty's Sloop Racehorse from July 3d to August 22d", 1773. The edge of the pack ice is delineated. From Phipps (1774: facing p. 76).

of the Carcass, from whose account these extracts come, provides an observant and sometimes poetic description of Spitsbergen "this forlorn country", its fauna and flora. Space permits only one more quotation, "The air about Spitsbergen is never free from icicles. If you look through the sunbeams transversely as you sit in the shade, or where you see the rays confined in a body, instead of dark motes...you see myriads of shining particles that sparkle like diamonds, and when the sun shines hot, as it does, so as to melt the tar in the seams of ships when they lie sheltered from the wind, these shining atoms seem to melt away and descend like dew".61

The ships got under way again on 18 July and stood to the northward with a westerly breeze. Ice stopped their progress, however, and for several days they coasted along its southward edge looking for openings to the north. Having found it fast both to north and west, Phipps decided to ply to the eastward. On 24 July at 2:00 a.m. (ship time), while to the northeast of Hakluyt's Headland, they "wore ship in the loose ice, which carried away the Pipe of the head Pump \& broke some of the Moulding in the Stern"'.62 On the afternoon of the 25 th, Moffen Island was sighted. Since the Carcass was becalmed very near to this low flat island, the same evening Captain Lutwidge sent the master on shore with a party of men in the longboat. So many birds of many different sorts were breeding there - "geese, ducks, burgomasters, ice-birds, malamucks, kirmews, rotgers" and almost every species peculiar to the climate, that the men had difficulty walking without filling their shoes. ${ }^{63}$ Phipps (1774:53-54) quotes Captain Lutwidge's concise description of the island, ${ }^{64}$ which had a shallow pond in the middle. The island was the last resting place of a Dutchman buried there in July 1771. The writer of the anonymous account ${ }^{65}$ gives a far less formal narrative of proceedings on shore, particularly of the master's encounter with a polar bear. A "full fathom in the belly and always the boldest man in the company over a bottle of sack", he was said to think no more of "killing a bear than of killing a gnat". However, in running away from the bear, "Major Buz"'66 dropped his gun and in stooping to recover it stumbled against a goose-nest, fell into it, and nearly smothered the goose upon her eggs. Before the unfortunate master could rise, the enraged gander came flying to the assistance of his halfsmothered consort, and missing his eye, "discharged his fury plump upon his nose". The crew eventually came to the rescue and the bear was shot. Two polar bears and a walrus were killed on the island, the latter with the aid of a boat from the Racehorse.

Phipps makes an interesting remark about Moffen Island, expressing surprise that none of the old navigators, "so accurate and minute in their descriptions of the coast", take notice of it. He wonders if in fact it was raised since their day by the meeting of the currents from "the great ocean" flowing north through "Waygats" (Hinlopen) Straits and along the west coast of Spitsbergen (Phipps, 1774:54).

The ships continued to work their way towards the northeast and by the 27th reckoned to be in Lat. $80^{\circ} 48^{\prime} \mathrm{N}$, their furthest north, when they were stopped again by the ice. They investigated each of several openings, some two or three miles deep, to the northward, forcing the ships by press of sail into heavier ice than found further to the west. The anonymous Newbery narrative describes the transient beauty of the scene:

... the air being perfectly serene, and the weather moderate, the fishes seemed to enjoy the temperature, and to express it by their sporting. The whales were seen spouting their fountains towards the skies, and the fin fish following their example. They likewise. . .saw dolphins; the whole prospect in short was 
more pleasing and picturesque than they had yet beheld in this remote region. The very ice in which they were beset looked beautiful, and put forth a thousand glittering forms, and the tops of the mountains, which they could see like sparkling gems at a vast distance had the appearance of so many silver stars illuminating a new firmament.

This description, whether actually written by "our journalist" of the Carcass or later embellished by his publisher, was doubtless inspired, as was Phipps on occasion, by an eighteenth century love of the picturesque. ${ }^{67}$

By 29 July, the ships were near "Waygats" (Hinlopen) Straits that divide Spitsbergen from North East Land. Two of the officers from the Racehorse went with a boat in pursuit of walrus and landed on Low Island. Dr. Irving was in the party and his description of the island is quoted by Phipps (1774:58-59) much as follows: there were several large fir trees on the shore, 16 or 18 feet above the level of the sea, some 70 feet long, and either cut down by the axe or torn up by the roots. The beach was formed of old timber, sand, and whalebones. The island was larger than Moffen, being some seven miles long. Stone hexagons provided easy walking, while the middle of the island was covered with moss, scurvy grass, sorrel, and a few ranunculas then in flower. One of two reindeer was killed. A fox, many snipe and nesting ducks were seen, as well as wild geese feeding by the waterside. On their way back to the ship, having fired at a walrus, the party was attacked by a number of others, which nearly stove the boat. However, a boat coming to their aid from the Carcass, helped to disperse the angry beasts. The midshipman in command of this boat was Horatio Nelson (Conway, 1906:281).

Nelson's more famous exploit - his encounter with a polar bear when he was 14 - is narrated in Clarke and M'Arthur's biography of 1810 , as follows:

There is an anecdote recollected by Admiral Lutwidge which marked the filial attention of his gallant coxswain. Among the gentlemen on the quarter-deck of the Carcass. . . there was . . . a daring shipmate of his [Nelson's] to whom he had become attached. One night during the mid-watch, it was concerted between them that they should steal together from the ship, and endeavour to obtain a bear's skin. The clearness of the nights in those high latitudes rendered the accomplishment of this object extremely difficult: they however seem to have taken advantage of the haze of an approaching fog, and thus to have escaped unnoticed. Nelson in high spirits led the way over the frightful chasms in the ice, armed with a rusty musket [Fig. 16]. It was not however long before the adventurers were missed by those on board; and, as the fog had come on very thick, the anxiety of Captain Lutwidge and his officers was very great. Between three and four in the morning the mist somewhat dispersed, and the hunters were discovered at a considerable distance, attacking a large bear. The signal was instantly made for their return; but it was in vain that Nelson's companion urged him to obey it. He was at this time divided by a chasm in the ice from his shaggy antagonist, which probably saved his life; for the musket had flashed in the pan and their ammunition was expended. Never mind, exclaimed Horatio, do but let me get a blow at this devil with the but end of my musket, and we shall have him. His companion, finding that entreaty was in vain, regained the ship. The Captain, seeing the young man's danger, ordered a gun to be fired to terrify the enraged animal.
This had the desired effect; but Nelson was obliged to return without his bear, somewhat agitated with the apprehension of the consequence of this adventure. Captain Lutwidge, though he could not but admire so daring a disposition, reprimanded him rather sternly for such rashness, and for conduct so unworthy of the situation he occupied; and desired to know what motive he could have for hunting a Bear? The being thought by his Captain to have acted in a manner unworthy of his situation made a deep impression on the high-minded coxswain; who pouting his lip, as he was wont to do when agitated, replied, "Sir, I wished to kill the bear, that I might carry its skin to my Father'".

(Clarke and M'Arthur, 1810:7.9).

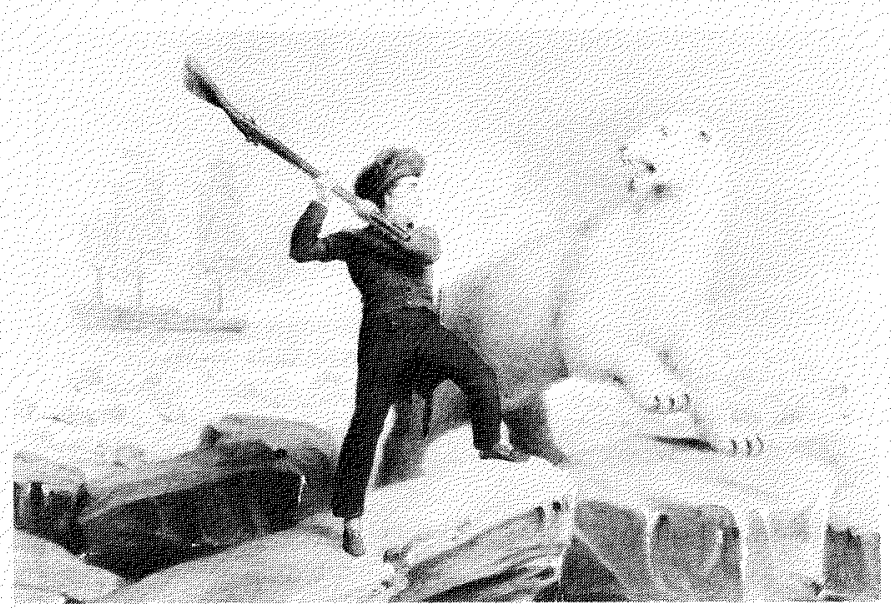

FIG. 16. Nelson and the bear. Oil by Richard Westall (1781-1850). National Maritime Museum. Reproduced by kind permission of the Trustees.

By $30 \mathrm{July}$, they were in Lat. $80^{\circ} 31^{\prime} \mathrm{N}$, Long. $18^{\circ} 48^{\prime} \mathrm{E}$, among the Seven Islands, to the northeast of Spitsbergen. Mr. Crane, the master of the Racehorse, was sent with a fouroared boat, to reconnoitre a passage through the ice and to ascertain its extent to the east and north. He and Captain Lutwidge climbed a hill on one of the islands ${ }^{68}$ from whence the ice appeared unbroken to the horizon. Lutwidge made the following entry in his log:

There now appeared no farther open water or passage for the ships, the main body of ice seems to be firmly joined from one island to another. I went in the boat to one of these islands, about 5 or 6 miles, to the NEwd of the ships, through narrow channels, being obliged to hawl the boat over the ice in several places. Here I had an extensive view of the sea to the eastward, which was entirely frozen over, not like the ice we had hitherto coasted, but a flat even surface, as far as the eye could reach, which was undoubtedly 10 leagues at least, as the weather was remarkable fine and clear, and the hill I was upon, about 200 yards above the surface of the sea. A compact body of ice joined to all the islands and lands in sight and no appearance of water, except the stream along the NE land, the way the ships came in. ${ }^{69}$

There was not a great deal of driftwood on the island, but some of it was thrown up far beyond high-water mark. There were many "deers horns" lying on the ground and the footprints of deer and bears were everywhere in the snow. The island was three to four miles long, with no sign of vegetation, except on some patches among the broken precipices. 
The anonymous narrative ${ }^{70}$ tells us a little more. The party was first met on the island by a herd of deer "so very tame, that they seemed as curious to gaze at the strangers, as the strangers were pleased to see them". They could easily have been killed with the thrust of a bayonet, but the "gentlemen, however, suffered only one of these fearless innocents to be fired at, and that was done by a sailor when they were absent on observation'". The writer remarks that here was proof that animals are not naturally afraid of man. The haziness of the mountain tops prevented their being observed with the instruments that had been carried up the hill and the gentlemen descended, disappointed. The scene on their return was described by Phipps (1774:60) as "beautiful and picturesque; the two ships becalmed in a large bay, with three apparent openings between the islands which formed it, but everywhere surrounded with ice as far as we could see, with some streams of water; not a breath of air, the water perfectly smooth, the ice covered with snow, low and even, except a few broken pieces near the edges.'
The two ships, fastened to the ice with ice anchors, filled their casks the next day with fresh water, the weather continuing fine. The ship's company of the Racehorse amused themselves on the ice all day (Phipps, 1774:61). Some of them are seen playing leap-frog in Cleveley's "View of the Racehorse and Carcass July 31st, 1773"' (Figs. 17, 18). The pilots, who, it will be remembered, were specially recruited for the voyage from among the Greenland whaling masters, were not nearly so carefree. "Being much further to the North and East than they had ever been and the season advancing they seemed alarmed at being beset" (Phipps, 1774:61). No doubt they had had experience of what this might mean; especially as no other vessels were nearby. A dock was cut in the ice and the immediate danger averted. ${ }^{71}$ A conference was held by Phipps of the officers, pilots and masters as to what was to be done; and "it was unanimously agreed that their deliverance was hopeless" and that the choice was between wintering on one of the islands or escaping by boat across the distant open sea. ${ }^{72}$ The men were sent to their quarters to sleep; the anonymous New-

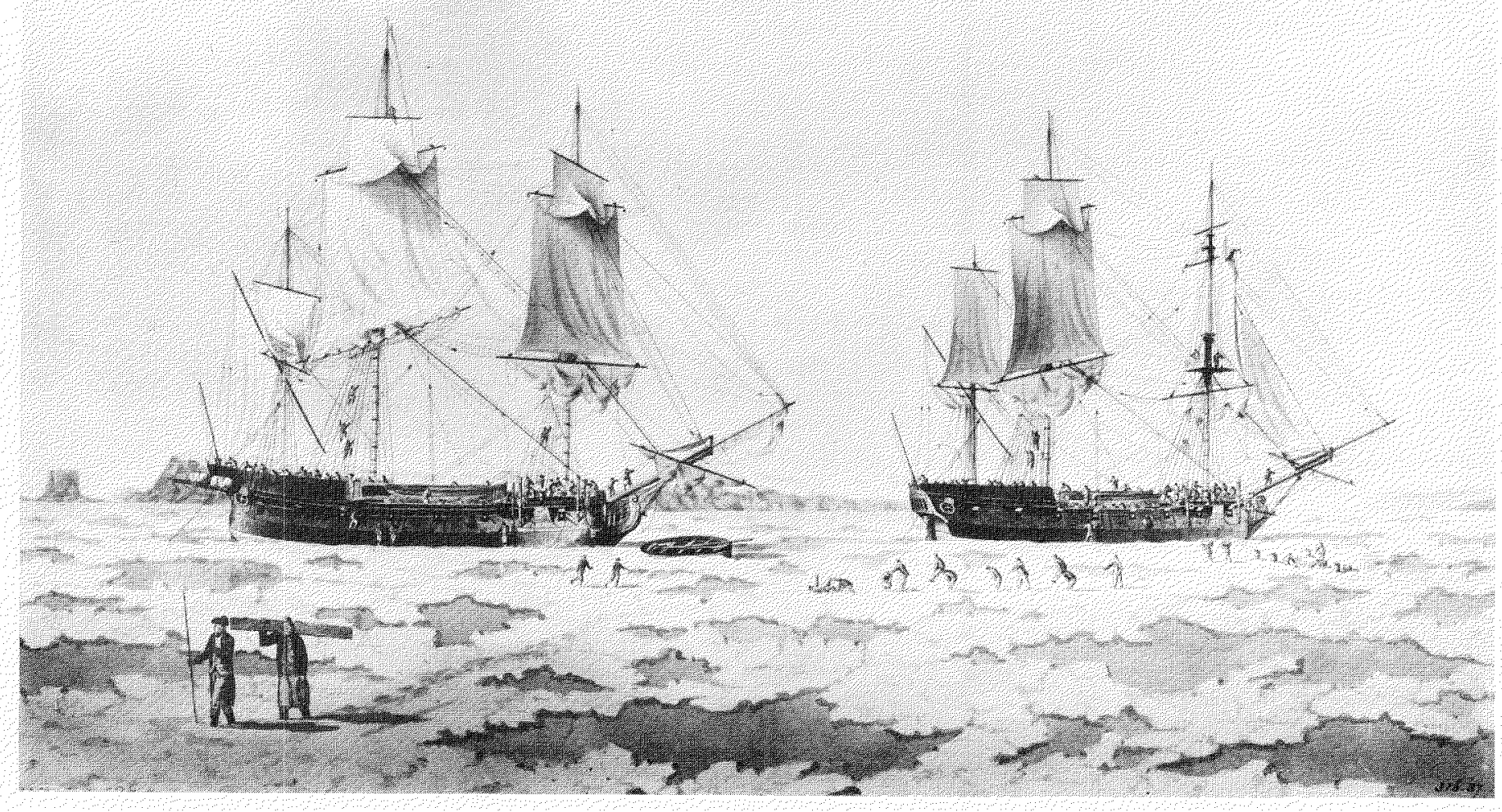

FIG. 17. The Racehorse and the Carcass in the ice, 31 July 1773, from sketches done during the expedition by d'Auvergne. Watercolour by John Cleveley, Jr. (1747-1786) in the Victoria and Albert Museum. Reproduced by kind permission of the Director. There is a version of this in the Print Room of the National Maritime Museum which lacks the figures in the left foreground, as does the engraving in Phipps (1774) dated 4 May 1774, Cleveley delint. Pouncy sculpt. 


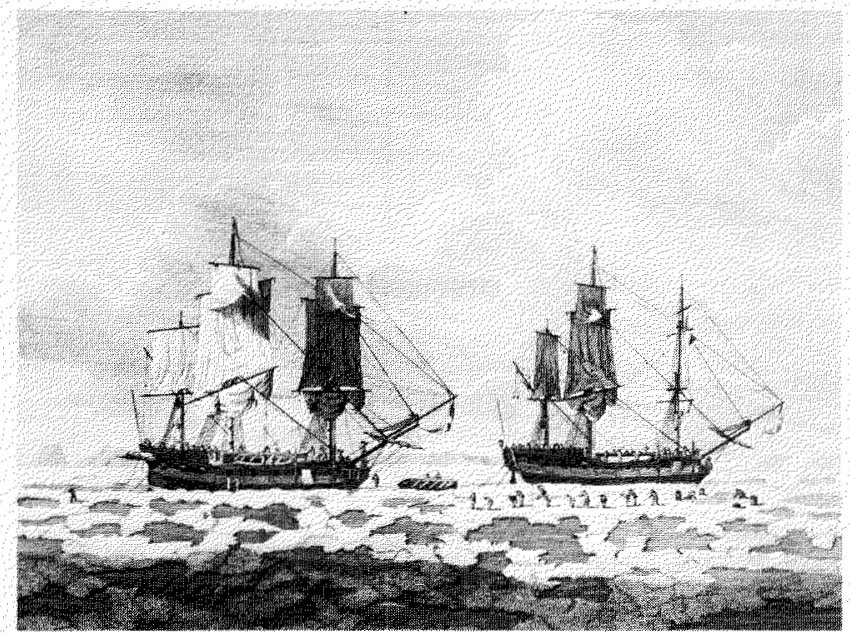

FIG. 18. "View of the Racehorse and Carcass July 31st 1773'. From Phipps (1774: following p. 60).

bery narrator remarks that "while their commanders preserve their fortitude, the sailors never lose their courage. They rose in the morning with as much alacrity and unconcern, as if they had been sailing with a fine breeze in the British Channel". ${ }^{73}$ They were set to work "with ice-saws, axes, sledges, poles and the whole group of sea tools" $" 74$ to cut a passage through the ice to the west, sometimes sawing through ice 12 feet thick (Phipps, 1774:62). A whole day's work (3 August) only resulted in moving the ships three hundred yards, while they had in reality been drifted with the ice to the northeast and east by the current (Phipps, 1774:62). The Carcass had been made fast to the stern of the Racehorse and Captain Lutwidge observed in his log that "the weather was remarkably warm at noon, the tar running upon the side, anchor stocks etc. where the sun shone upon them, yet the water on the opposite side where the ice was removed was freezing on the surface'". 75

By 5 August the likelihood of getting the ships out seemed less and less and as the season was already far advanced, Mr. Walden, ${ }^{76}$ one of the midshipmen, was sent with two pilots to an island about 12 miles away (afterwards called by Phipps "Walden's Island"), to see where open water lay (Phipps, 1774:63). They returned the next morning to say that the ice was open further to the westward. Phipps decided to try to escape in the ships' boats, making for the Dutch whalers at Hakluyt's Headland, rather than attempting to winter in the ships, with no harbour and in shoal water, where they might be crushed or wrecked. The officers of both Racehorse and Carcass were informed of the decision and the boats were immediately hoisted out onto the ice and preparations begun to make them secure and comfortable, by "rising them with light Stantions and Tarpawlins". ${ }^{77}$ This was on 6 August (Phipps, 1774:65). Phipps ordered canvas bread bags to be made in case it proved necessary suddenly to abandon ship. Meanwhile, those who were not busy fitting the boats or preparing the food for them hunted the polar bears that made their way to the ships, probably attracted by the savoury smell of the provisions being cooked. ${ }^{78}$
The writer of the narrative published by Newbery gives a most sensitive account of the death of a she-bear and cubs: ${ }^{79}$

The Polar Bear and her cubs, which were almost as big as she, were pulling away pieces of flesh from a fire on the ice, in which were burning the remains of a Walrus, killed some days before. Some of the crew amused themselves by throwing additional pieces from the ship onto the ice "which the old bear fetched away singly, laid each lump before her cubbs as she brought it, and dividing it, gave each a share, reserving but a small portion to herself. As she was fetching away the last piece... they levelled their muskets at the cubbs and shot them dead; . . . they also wounded the dam, but not mortally. It would have drawn tears of pity from any but unfeeling minds, to have marked the affectionate concern expressed by this poor beast, in the dying moment of her expiring young. Tho' she was sorely wounded, and could but just crawl to the place where they lay, she carried the lump of flesh she had fetched away, as she had done the others before, tore it in pieces, and laid it down before them, and when she saw that they refused to eat, she laid her paws first upon one, and then upon the other, and endeavoured to raise them up. All this while it was pitiful to hear her moan. When she found she could not stir them, she went off, and when she had got at some distance, looked back and moaned, and that not availing to entice them away, she returned, and smelling round them, began to lick their wounds. She went off a second time, as before, and having crawled a few paces, looked again behind her, and for some time stood moaning. But still her cubbs not rising to follow her, she returned to them again, and with signs of inexpressible fondness, went round one and round the other, pawing them, and moaning. Finding at last that they were cold and lifeless, she raised her head towards the ship, and, like Caliban in the tempest, growled a curse upon the murderers, which they returned with a volley of musket balls. She fell between her cubbs and died licking their wounds."'80

On 7 August Phipps set out with the launch. It proved possible for officers and $\mathbf{4 0}$ men to haul her about two miles (Fig. 19). A studding sail was cut up "to make Belts for the

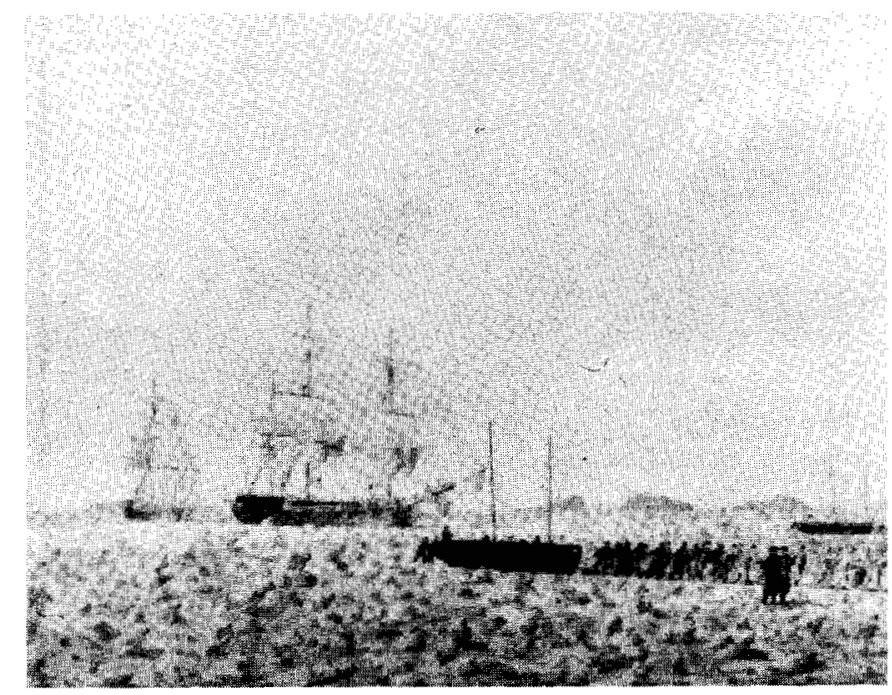

FIG. 19. Hauling boats over the ice off Spitsbergen, 7 August 1773. Watercolour by Cleveley from sketches by d'Auvergne. British Museum, Department of Prints and Drawings. Reproduced by kind permission of the Trustees. There is a version of this in the Print Room of the National Maritime Museum, and an engraving in Phipps (1774) dated 4 May 1774, Cleveley delint. No engraver given. Other smaller engravings were done elsewhere. 
Men to drag the Boats over the Ice" ${ }^{81}$ The ships (in Captain Lutwidge's charge) also made about a mile to the west. Phipps resolved to carry on both attempts together, moving the boats constantly, without omitting any opportunity of getting the ships through. The situation is vividly shown in John Cleveley's "View of the Racehorse and Carcass, August 7th, 1773". Midshipman Floyd recorded that each man was allowed a musket, a 30-lb bag of bread, and no more clothes than he stood up in. "I therefore went down", he says, "and put on me two shirts, two waistcoats, two pairs of breeches, four pairs of stockings, a large pair of boots, a good hat and stuck a pistol which I had into a canvas belt, which latter at the same time served to keep from falling the few sheets of my journal I had written on the progress of our voyage. The belt was to fasten a rope to assist in dragging a boat. I likewise put in my pocket, a comb, a razor, a pocket-book full of letters, and some pistol shot, also a red woollen cap which I put on my head under my hat" (Markham, 1879:199). Because of the order about clothes, the officers put on flannels and the common men wore what the officers had thrown off, said the anonymous Newbery author. "It was inconceivably laughable to see these motley bands yoked in their new harness; and to say the truth, there was not one solemn face among the two companies. That headed by the Commodore [i.e. Phipps] drew stoutly for the honour of their leader, and that headed by the Lieutenants had their music to play to them, that they might dance it away, and keep pace with the Commander in chief'".82 Phipps (1774:66) remarks that the people behaved very well in hauling the boat, seeming reconciled to the idea of quitting the ships, and having the fullest confidence in their officers. This last observation is borne out by the Newbery account, which says that both their Commanders and the two Lieutenants were "deservedly beloved, particularly Lieutenant Beard" (John Baird, First Lieutenant of the Carcass); the other was Henry (later Admiral Sir Henry) Harvey, First Lieutenant of the Racehorse.

It may be imagined that young Midshipman Nelson did not stand idly by. "When the two boats were fitted out to quit the two ships blocked up in the ice", he wrote in his Memoir, "I exerted myself to have the four oared cutter raised upon [i.e. the sides heightened for added protection] which was given me with twelve men; and I prided myself in fancying I could navigate her better than any other boat in the ship" (Clarke and M'Arthur, 1810:7). ${ }^{83}$ One wonders if something of the later "Nelson touch" may have stemmed from the example of the First Lieutenant of the Carcass in which Nelson served. The Newbery narrative singles out John Baird for special praise, observing that his "steady and uniform conduct in times of the greatest danger, cannot be sufficiently admired or applauded. Neither swayed by passion, nor disconcerted by the sudden embarrassments that often intervened, his conduct was always calm, and his orders resolute. He never was heard, during the whole voyage on the most pressing emergencies, to enforce his commands with an oath, or to call a sailor by any other than his usual name; and so sensible were they of his manly behaviour, that, when the ship was paid off at Deptford, they were only prevented by his most earnest request from stripping themselves to their shirts, to cover the streets with their cloaths, that he might not tread in the dirt in going to take coach"' ${ }^{84}$ One is tempted to doubt the truth of such a eulogy, but judging from the rest of the narrative, it may well be accurate enough.

To return to the ships in the ice: after six hours of tremendous effort on 7 August, the launches had been moved a single mile and it was time to dine. Captain Phipps had been labouring with his men, and it was in character, says the Newbery narrative, that he should also dine with them. The amusing story of how this happened is told as follows: ${ }^{85}$

The Cook with his mates (who were bringing the Commodore and the officers their dinners under covers) to keep out the cold after coming from a warm fire-side, had made a little too free with the brandy bottle before they set out, and before they had got half way to the lances, the liquor began to operate; the Cooks were sometimes very near boarding each other, sometimes they hauled off, and sometimes steered right a-head. At length coming to a chasm, or parting of the ice, which they were obliged to leap, down came the master Cook, with dish, cover, meat and all; and what was still worse, though it was not then thought of much value, the Commodore's common service of plate, which the Cook carried for the officers to dine on, fell in the chasm and instantly sunk to the bottom. This accident brought the Cook a little to himself, and he now stood pausing whether he should jump down the gulph after the plate, or proceed to the Commodore to beg mercy and make his apology. His mates persuaded him to the latter, as the Commodore was a kindhearted gemman, and would never take a man's life away for a slip on the ice. Besides, it was a great jump for a fat man, and Commodore, they were sure, had rather lose all the plate in the great cabin, than lose Cookie. Comforted a little by this speech, the Cook proceeded, but let his mates go first with what remained, to carry the tidings of what befell the rest. When the Commodore had heard the story, he judged how it was with them all. But where is the Cook, said he to the mates? He's crying behind, an please your Honour. In the mean time, the Cook came up. Cook, said the Commodore, bring me your dinner. I will dine to-day with my comrades. My dinner! Ay, a pound of flesh next my heart, if your Honour likes it. The promptness of the reply shewed the sincerity of the Cook's good-will, and pleased the Commodore better than a feast upon turtle. He dismissed him with a smile, and partook with the officers in what was left, who made up their dinners with a mess from the common men.

On 8 August, two pilots who were sent to see the state of the ice to the westward reported it to be heavy, close, and consisting chiefly of large fields. Phipps set out again with the men in the forenoon and they hauled the launches a further three miles (Phipps, 1774:66). "The weather being foggy", wrote Phipps in his book, "and the people having worked hard, I thought it best to return on board between six and seven" (Phipps, 1774:66). The ships were warped a short distance through some small openings in close and heavy ice during the morning of the 9th, which was foggy. When the day cleared, it was seen that much greater progress towards the west had been made than expected, and with hard work during the day, the vessels were moved still further through the ice, which was itself fast drifting in the right direction. They passed the launches, which were hoisted on board (Phipps, 1774:67). The Carcass cast loose from the Racehorse and set 
sails to follow her.$^{86} \mathrm{~A}$ westerly wind brought snow and made them drift eastward for a short but agonizing period. "The people have been much fatigued", Phipps wrote in his journal, "which obliges me to desist from working for a few hours, as I find, without rest and good feeding Men can do nothing here, but with Management can make great efforts"' ${ }^{87}$

A typical entry for this period occurs in the Captain's log of the Racehorse, for the nautical day of Tuesday 10.August.

Little Wind and foggy with Snow and Sleet. PM employed warping the ship through the Ice. At 4 the Ice closing carried out the Hooks and Hawsers to steady the Ship. At 6 the Ice opening, we again warped her through it. At 9 sent an Officer and 25 Men from each Ship to bring the Launches over the Ice to the Ships. At 3 am hoisted the Launch up alongside the Ship; and the Ice closing again carried out the Hooks to steady the Ship and furl'd the Sails. At 7 the Ice opening we loosed the Sails; at 8 saw the Land bearing $S 10^{\circ} \mathrm{W}$. At 8 there being two large Islands of Ice on our Bows, we carried out the Ice Hooks astern to hand the Ship by 'till they separated; at $1 / 2$ past 9 we got between them \& kept the Ships head in a small opening to the SW. At 10 fresh. Gales \& hazy, we made all the Sail we could to force her thro' it, often striking very hard against the Ice. At 11 we struck an Island of Ice with the Starboard. Bow, and the lower part of the best Bower Anchor Stock taking the Ice, broke the shank of the Anchor close to the Stock. At Noon fresh Gales \& squally, running through the Ice, the openings being yet very narrow we often struck very hard against the loose pieces. The Carcass in Company.

\section{Deliverance came on 10 August (civil time): Phipps briefly} summed up the day as follows:

The wind springing up to the NNE in the morning, we set all sail we could on the ship, and forced her through a great deal of heavy ice: she struck often very hard, and with one stroke broke the shank of the best bower anchor. About noon we had. got her through all the ice, and out to sea. I stood to the NW to make the ice, and found the main body just where we left it. At three in the morning, with a good breeze Easterly, we were standing to the Westward, between the land and the ice, both in sight, the weather hazey.

The sight of clear water from the masthead made joy spread "like wildfire...throughout the ship at this news". (Markham, 1879:203). "Then festivity and jollity took place of abstinence and gloomy apprehensions", says the Newbery narrative, "and before they arrived at Spitsbergen, there was not a sailor on board with a serious face". They now had time to admire the ice, exercising their imaginations in describing its curious and varied forms.$^{89}$ Cleveley once more illustrated the scene from d'Auvergne's sketches, with his picture of "The Racehorse and Carcass forcing through the ice, August 10th, 1773"' (Fig. 20).

They came the next day to anchor in the harbour of Smeerenberg "to refresh the people after their fatigues" (Phipps, 1774:68). Four Dutch ships were still there "upon which I had depended" wrote Phipps, " "for carrying the people home in case we had been obliged to quit the ships' (Phipps, 1774:68). The Dutchmen informed him that all the English ships had set sail for home on $10 \mathrm{July,} \mathrm{"the} \mathrm{day} \mathrm{to} \mathrm{which} \mathrm{they} \mathrm{are} \mathrm{obliged}$ by contract, to stay to entitle their owners to receive the bounty-money, allowed by Parliament for the encouragement

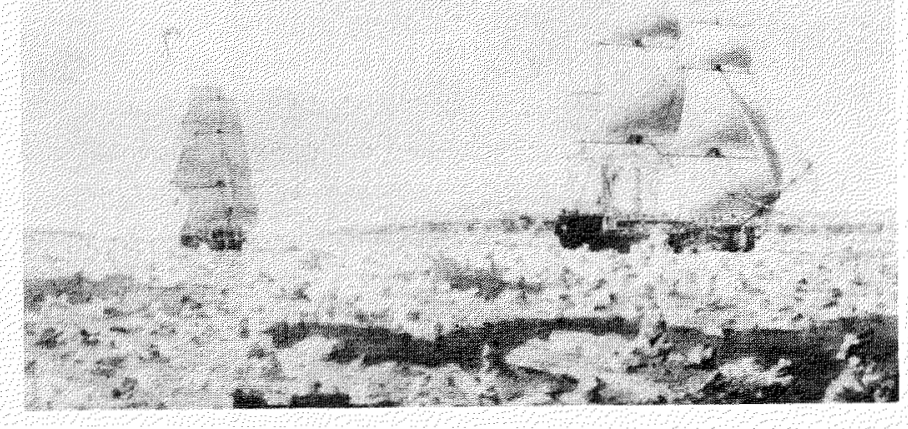

FIG. 20. The Racehorse and Carcass forcing their way through the ice, 10 August 1773. Watercolour by Cleveley from sketches by d'Auvergne. British Museum,. Department of Prints and Drawings. Reproduced by kind permission of the Trustees. There is a version of this in the Print Room of the National Maritime Museum and an engraving in Phipps (1774) dated 4 May 1774, Cleveley delint. P.C. Canot sculpt.

of that fishery" .90 The majority of the Dutch vessels usually set sail from Spitsbergen at about that date, but they took turns to stay behind until the severity of the weather forced them to depart. The reason for this practice was to pick up "such men as may by accident have lost their ships in the ice, and who; notwithstanding, may have had the good fortune to save their lives by means of their boats".91 The anonymous Newbery narrator praised the Dutch government for this "very humane institution", whereby each year about five whaling ships were left to wait and were obliged to send out their boats daily "in search of their unfortunate fellow subjects", some of these boats' crews themselves suffering severely at times.

Phipps (1774:68) remarks that the Dutch whalers used to boil their oil on Amsterdam Island and that "the remains of some convenience erected by them for that purpose are still visible". On 12 August the instruments were landed and the tent pitched, but bad weather prevented observations being made until the 14th. These were completed on the 18th. Dr. Irving climbed another mountain with the barometer to ascertain its height. (There is no mention of the black dog, this time.) Phipps took a survey of this part of Fair Haven to connect it with the one made earlier of the other part. Latitude and longitude were determined by repeated observations.

The Newbery narrative adds a little to what Phipps says above. "They found, on the examination of the vibration of the pendulum, that it differed from that at Greenwich by Harrison's time-keeper only two seconds in forty-eight hours, which time-keeper, at their arrival at Greenwich, varied only one second and a half from the time-pieces at the observatory there. Mr Robinson, who was articled to Commodore Phipps, from Christ's Hospital, and who does honour to that noble foundation, was particularly careful to note the result of all the observations that were made in this high latitude".${ }^{93}$ The writer tells us, too, that the ovens were taken on shore, and a 
"considerable quantity of good soft bread baked for the refreshment of the men", 94 Phipps being solicitous, as always, for their welfare. There was much work to do on the ships 'overhauling the rigging, tarring the ships' sides, taking in water, peying and securing the masts", 95 ready either for further exploration or for the voyage home.

Phipps provides one of his fairly rare descriptive passages when writing of the "Iceberg" - or glacier, as it would now be called - at Fairhaven. ${ }^{96}$ His description is as follows:

Opposite to the place where the instruments stood, was one of the most remarkable Icebergs in this country, Icebergs are large bodies of ice filling the vallies between the high mountains, the face towards the sea is nearly perpendicular, and of a very lively light green colour. That represented in the engraving, from a sketch taken by Mr D'Auvergne upon the spot, was about three hundred feet high, with a cascade of water issuing out of it. The black mountains, white snow, and beautiful colour of the ice, make a very romantick and uncommon picture. Large pieces frequently break off from the Icebergs and fall with great noise into the water: we observed one piece which had floated out into the bay, and grounded in twenty-four fathom; it was fifty feet high above the surface of the water, and the same beautiful colour as the Iceberg.

The watercolour by John Cleveley is reproduced in this paper (Fig. 21; also see Fig. 22). Phipps (1774:71-72) goes on to make some general remarks about Spitsbergen and about the sea ice. The Racehorse and Carcass weighed on the morning of the 19th and made another effort to penetrate the pack to the northwest, still searching for a passage towards the Pole. This attempt came to nothing and the season being "so very far advanced" (Phipps, 1774:73), with gales and fog to be expected, it was time to head for home. The preceding weeks of favourable weather had enabled them, wrote Phipps (1774:74), to ascertain "repeatedly the situation of that wall of ice, extending for more than twenty degrees between the latitudes of eighty

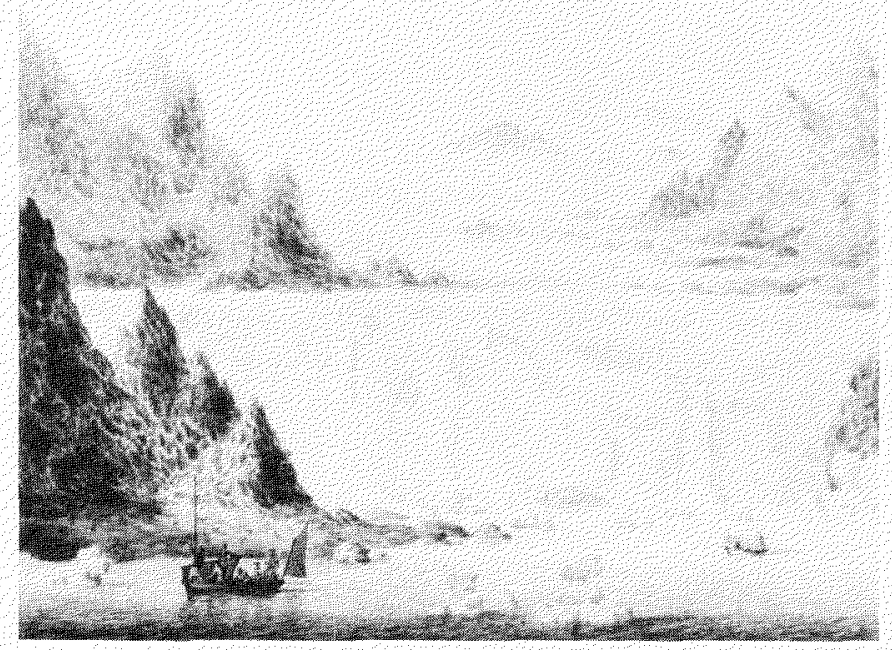

FIG. 21. View of an iceberg; Fair Haven, Spitsbergen, 18 August 1773. Watercolour by Cleveley from sketches by d'Auvergne. British. Museum, Department of Prints and Drawings. Reproduced by kind permission of the Trustees. There is an engraving of this, " W. Pars del"', in Phipps (1774) by W. Byrne. This glacier has been identified as Kennedybreen by Norsk Polarinstitutt, Oslo. In the left foreground can be seen the graves of the old Dutch whalers on Likneset (Deadmen's Point). and eighty-one, without the smallest appearance of any opening".

During the homeward voyage, on 4 September, another deep sounding was made between Iceland and Norway, striking ground in 683 fathoms (Phipps, 1774:74). It took eight hours for the men to heave up the lead with the capstan. ${ }^{97}$ Strong gales with a great sea followed and caused the separation of the ships. The Racehorse lost three of her boats and had to heave two guns overboard. In one of these gales, on 12 September Dr. Irving took the temperature of the sea "in that state of agitation" and found it considerably warmer than that of the atmosphere. It was found necessary to scuttle the launch on the main deck of the Carcass and to get her cleared ready to throw overboard if the gale increased. In one very hard squall the ship was almost waterlogged from the weight of water on her decks. ${ }^{98}$

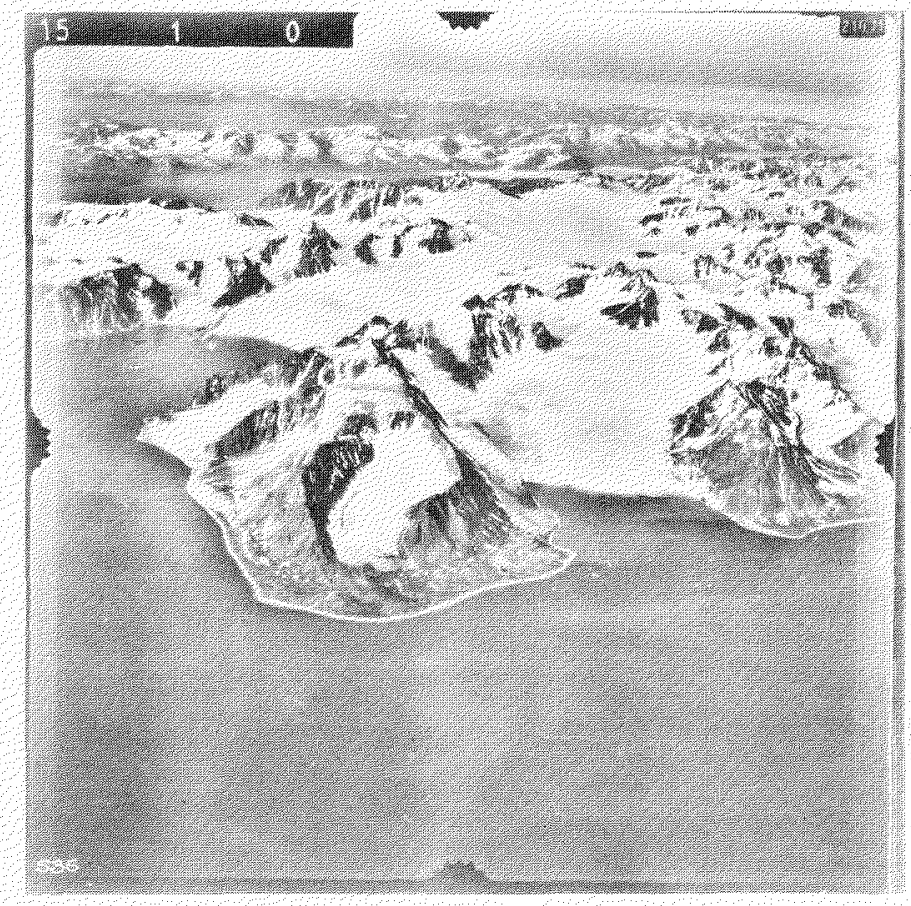

FIG. 22. Kennedybreen and area, Spitsbergen. Aerial photograph by Norsk Polarinstitutt, Oslo. Phipps's "Iceberg, Fair Haven" (Fig. 21) is to the right and bears the modern name Kennedybreen.

\section{CONSEQUENCES OF THE VOYAGE}

\section{Publications}

The anonymous narrative of the voyage which had been quoted above was published by Newbery in February $1774 .{ }^{99}$ Phipps's own Voyage was not published until the late summer, being noticed in the Gentleman's Magazine of September. His book contains some 70 pages of narrative, followed by an Appendix which is more than twice as long. In it are set out all the tabulated observations and other scientific and navigational results, including the description of the polar bear (Ursus maritimus Phipps) and the Ivory Gull, which Phipps calls Larus niveus, previously noted. The Gentleman's Magazine ${ }^{100}$ praised the appendix in these words: 
The appendix to this curious voyage, which does equal honour to the navigator and the nation, contains not only the result of the observations and experiments made throughout the course of it, but also full detail of the whole process of investigation, that those who may be so minded, may re-examine the facts and judge of the solidarity of the conclusions. Certain it is, that there has not appeared a voyage in any language so replete with nautical information, nor in which the mariner and philosopher can find such liberal entertainment:

The French philosopher D'Alembert was of the same opinion. In thanking Phipps for a copy of the book, he wrote: "Il sera lu avec profit par les Géographes, les navigateurs, les astronomes et les physiciens; et toutes les sociétés savantes doivent s'empresser d'en orner leur Bibliothèque". ${ }^{101}$ The whole is dedicated by Phipps to King George III, with whom he and Captain Lutwidge were reported to have had several conferences on their return from the north. ${ }^{102}$ Some correspondence survives between author and publisher in the Mulgrave papers, including letters from Abbé André Morellet concerning the French translation (Fig. 23), which appeared in 1775. ${ }^{103}$ The Abbé informed Phipps that the translation had been done by "un de mes amis qui entend fort bien votre langue et qui est aussi versé dans les connoissances de la marine qu'un homme de lettres peut le devenir dans le cabinet en lisant les ouvrages qui y ont rapport'. ${ }^{104}$ A German translation with added commentary was done by Samuel Engel and published in Berne in 1777 (Martin-Allanic, 1964:1387). A scientific postscript by Dr. Samuel Horsley appeared shortly after the English publication of the Voyage. This was entitled Remarks on the observations made in the late voyage towards the North Pole for determining the acceleration of the pendulum, in Latitude $79^{\circ} 50^{\prime}$, in a letter to the Hon. Constantine John Phipps (London, 1774). Published with Phipps's consent, the pamphlet pointed out errors in calculations made by Israel Lyons. Phipps was 'much vexed at Lyons' blunder as it gives an appearance of inaccuracy to the whole work which I flatter myself it does not merit". ${ }^{105}$

\section{Barrington, Engel and the North Pole}

Despite the inability of the Racehorse and Carcass to navigate further north than $80^{\circ} 1 / 2^{\prime}$, the Hon. Daines Barrington continued to provide evidence of voyages which had attained far higher latitudes. He read a paper to the Royal Society on 19 May 1774, which began, "As I was the unworthy proposer of the voyage towards the N Pole, which the Council of the R Society thought proper to recommend to the board of Admiralty, I think it my duty to lay before the Society much of the intelligence I have happened to procure with regard to Navigators having reached high Northern Latitudes; because some of these accounts seem to promise that we may proceed further towards the Pole than the very able officers who were sent on this destination last year were permitted to penetrate, notwithstanding their repeated efforts to pass beyond 80 degrees \& $1 / 2 " .{ }^{106} \mathrm{He}$ read a second paper on the North Pole to the Society on 22 December 1774 , presenting additional facts, together with "some general reasons. why it may be presumed that the polar seas are at least sometimes navigable". Al-

\section{$\mathrm{V} O \mathrm{Y} \mathrm{AE}$ \\ AU POLE BOREAL, \\ $A+2, N+273$}

DAR ORDRE DU ROIDAXGLETERRE, PARCONSTANTINAEAN BHTPS.

TRADUTTDE LANOLOKS

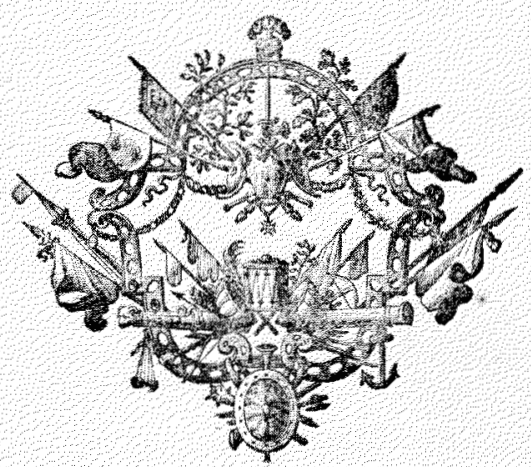

A P A R I S,

$\mathrm{Ch}_{2}$ S SAML ANT \& N ron, we Sanit Jean de Beaurais,

QPrsor, Quat des Augutins, pres la rue Git-le-Cour.

M. D C C L X X V.

AVEC APPROBATIONET PRATLEGE DU ROI.

FIG. 23. Title page of the French translation of Phipps's Voyage towards the North Pole, published in Paris in 1775.

though entirely satisfied with the "great abilities perseverance \& intrepedity" of the 1773 expedition, he conceived that "they were stopp'd by a most unfortunate barrier of ice (of great extent indeed) but which was only temporary and not perpetual.'. ${ }^{107}$ A postscript dated 8 January 1775 added three further examples of navigation in very high latitudes. ${ }^{108}$

Barrington and his fellow polar enthusiast, Samuel Engel, were brought into "a direct correspondence"' with each other after Phipps's return. ${ }^{109}$ An interesting commentary by Engel on broad aspects of the 1773 voyage survives in the Dartmouth Papers at Stafford, ${ }^{110}$ in which the Swiss geographer asked rhetorically: "Il s'agit de savoir pourquoi M Phipps a été enfermé par les Glaces? Si ceci contredit le moindre du Monde mon Système? Ou si au contraire il n'en prouve la plus parfaite solidarité'. Engel argued forcefully in this paper to fit the experiences of the Racehorse and Carcass into his general theory of the open polar sea. ${ }^{11}$ Despite Cook's lack of success in finding a passage to the North during his third voyage, the theory of the open polar sea lingered on. The Dorothea and Trent, despatched after the great wars, under Captain Buchan, R.N., were, however, unable in 1818 to reach as high a lati- 
tude as Phipps. The works of William Scoresby Jr., especially his Arctic regions (1820) brought the voice of experience and reality before the reading public of the early nineteenth century. It became evident that sledges, not sailing ships, would be first to reach the North Pole.

Although the Racehorse and Carcass thus sailed after a chimera, we may applaud the preparation, conduct, and enquiring scientific spirit of their voyage. Phipps had vainly ranged the close-packed ice in search of an opening to the north, but, as a contemporary wrote, "His misfortune will ever redound to his honor, as it proved his spirit, his perseverance and a soul fertile in expedients among the greatest difficulties" (Pennant, MS:266).

\section{APPENDIX A}

\section{INSTRUCTIONS TO LYONS}

[Printed from the Mulgrave papers]

By the Commissioners appointed by Acts of Parliament

for the discovery of longitude at sea \&c \&c

Whereas you have agreed (on certain terms) to go on Racehorse board one of His Majesty's Sloops named in the margin Carcass now fitting out for a Voyage to the North Pole in order to make nautical \& astronomical observations \& to perform other Services tending to the improvement of Geography \& Navigation, you are hereby required and directed to hold yourself in readiness to embark on board one of the said Sloops, when the necessary Orders shall be given for your reception and then to proceed in her on the above-mentioned Voyage accordingly; \& whereas we have ordered you to be supplied with the several Instruments, Books, Maps, Charts and other Things specified in the Schedule hereunto annexed, which the Astronomer Royal will cause to be delivered to you, you are to receive \& take into your charge \& custody the said. Instruments, Books, Maps, Charts etc. (giving our Secretary a receipt for the same) and to make use of them for the several purposes to which they are respectively adapted taking all possible care of them during the Voyage, and, when that shall be finished, returning them, in the best condition you may be able, to Us or our Secretary; and, in the performance of the above mentioned Service, you are punctually and faithfully to observe and execute the following Instructions:

\section{1st}

You are every Day if the Weather will admit, to observe meridian altitudes of the Sun for finding the Latitude, and also other altitudes of the Sun, both in the Morning and Afternoon at a distance from Noon, with the time between measured by a Watch; And the Sun's bearing by the Azimuth Compass at the 1st observation, in Order to determine both the apparent time of the Day and Latitude in case the Sun should be clouded at Noon; you are moreover, to observe distances of the Moon from the Sun and fixt Stars with the Hadley's Sextant from which you are to compute the longitude by the Nautical Almanac.

\section{2nd.}

You are to wind up the Watches every Day as soon after the time of noon as you can conveniently, and compare them together and set down the respective times; and you are to note also the times of the Watches when the Sun's Morning and Afternoon Altitudes, or the distances of the Moon from the Sun and fixt Stars, are observed; and to compute the Longitude, resulting from the comparison of the Watches, with the apparent time of the Day inferred from the Morning and Afternoon Altitudes of the Sun.

\section{3rd}

You are to observe, or assist at the observation of the variation of the Compass; and to observe the inclination of the Magnetic dipping needle from time to time.

\section{4th}

You are to Note the height of One or more Thermometers placed in the Air and in the Shade, early in the Forenoon and about the hottest time of Day; and to observe also the height of the Thermometer within the Vessel near the Watches, and to note the height of the Marine Barometer at the same time; and to make experiments of the Saltness of the Sea, \& the degree of Cold by letting down the Thermometer to great depths as you have opportunity.

\section{5th}

You are to keep a Ships Journal with the Log worked according to the Plain dead reckoning (Lee-way and variation only allowed) noting therein the length of the Log Line and times of the running out of the Sand-Glasses from time to time; And you are to insert therein also another Account corrected by the last celestial Observations, and a third deduced from the Watches.

\section{6th}

You are to teach such of the Officers on board the Vessel as may desire it the use of the Instruments, Books, Maps etc. which are put into your Hands, and the method of finding the latitude from two observed altitudes of the Sun with the time between measured by a Watch and the method of finding the Longitude from the Lunar Observations.

\section{7th}

You are to settle the position of Head-Lands, Islands, \& Harbours in Latitude \& Longitude by the celestial observations and also set down what Longitude the Watches give.

8th

Whenever you land you are to make the same observations on Shore as you have been above directed to do on Ship board only observing to take the Sun's altitudes by reflection from the Trough of Water or Quicksilver (with which you are provided for this purpose) instead of the Horizon of the Sea; And observe the height of the Tides and the time of high \& low water, particularly at the full and change of the Moon; and whether there be any difference and what, between the Night \& Day Tides.

\section{9th}

You are to take particular Care that all your observations, whether made on Ship board or on Shore, be kept in a clear distinct \& regular manner, in a Book wherein the Commander of the Vessel and other Officers may also insert their observations if they think fit, and that they be written therein with all their circumstances immediately after they are made or as soon after as they can be conveniently transcribed therein from the loose Papers or Memorandum Books in which they may have been first entered, which Book is to be always open for the inspection and use of the Commander and other Of- 
ficers of the Vessel; and you are to send to our Secretary, by every safe conveyance that may offer, the results of your several Observations and also the principal observations themselves; and lastly:

For your care and pains \& encouragement during the time you shall be employed on the Service you will be allowed $£ 150$ - clear of all expences. Given under our Hands the 24th Day of April 1773.

To Mr. Israel Lyons Sandwich Chas. Hardy

H. Palliser

A. Shepherd

Ph. Stephens

By Order of the Commissioners

Jno. Ibbetson

A Schedule of the Instruments, Books etc. etc. referred to in the beforegoing Instructions

A Brass Hadley's Sextant, by $\mathrm{Mr}$ Dollond, with $\mathrm{Mr}$ Maskelyne's \& Mr Dollond's new improvements.

A Wooden Trough for holding Water or Quicksilver, covered with a Glass roof to keep off the wind; designed for observing the Sun's double altitude by reflection on Land with the Hadley's Sextant etc.

One large Watch for keeping time at Sea by Mr Arnold and one by Mr Kendal.

An Achromatic Telescope of $3 \frac{1}{2}$ Feet with a treble object Glass, with an object Glass micrometer, by Dollond.

A Four feet Hand perspective by Dollond.

A variation Compass for Sea of the late Dr Knight's construction

2 magnetic dipping Needles; one fitted for using at Sea; and the other, of the nicest sort, for use at land.

A sett of Magnetic Bars to touch the Needles with.

A Marine Barometer.

6 Thermometers from 100 below 0 to 120 above.

2 Machines of Wood to enclose a Thermometer for trying the Cold of the Sea at different Depths.

Robertson's Navigation.

Haselden's Seaman's daily Assistant.

Sherwin's Logarithms

3 Variation Charts

Nautical Almanacs of $1771,1772,1773 \& 1774$.

6 copies of each.

Tables requisite to be used with nautical Almanacs 6 copies.

General Tables of refraction and parallax -2 copies.

Mayer's Tables, 1 copy.

An Equatorial Instrument.

An Astronomical Quadrant.

Exd, Memo Since the date of these Instructions he has been supplied with the following Instruments not included in the Schedule, viz.

\section{An Hydrostatic Ballance.}

Two Glass Vessels to measure Specific Gravity of Fluid.

A Wilson's Microscope.

\section{APPENDIX B}

\section{DR CHARLES IRVING AND SALT WATER DISTILLATION AT SEA}

Everyone has read of the barrels of stinking water provided on board the ships of the old sailing navy and merchant fleets. Lloyd and Coulter (1961:91-92) have said a little on the history of the distilling of sea water during long voyages to provide fresh water at sea. They tell us that James Lind's invention of 1762 at first found favour with the Admiralty. This was a simple method, using still heads or even musket barrels fitted to large coppers to draw off the steam evaporating from boiling sea water. The apparatus was successfully used by Wallis during his circumnavigation of 1766-68. However, as pointed out by Lloyd and Coulter, Lind's invention brought him little fame or reward, and in 1766 Pierre-Isaac Poissonnier, the French doctor and chemist, received a pension in France for something evidently closely resembling it (Lloyd and Coulter, 1961), which was used by Bougainville on his circumnavigation. In 1771, Charles Irving, "a junior surgeon in the Arrogant" (and the Irving of Phipps's voyage), "had the effrontery", write Lloyd and Coulter, "to invite Lind to a demonstration of a new and hitherto not practised method of distillation, which proved to be exactly similar to his own. 112 The doctor at first refused, but at length consented to sign it, desirous that in any form so important a discovery as the freshening of sea water by distillation might be introduced into general use; this, Mr Irving said, he had reason to believe he could effect if he obtained the certificate; and to me it appeared a matter of indifference whether the distillation was performed by means of a still head and refrigeratory, as I had proposed, or by a long thin tube wet with mops, as set forth in the certificate: in that particular alone Mr Irving's method having differed from what I had before published. The altruistic James Lind (1716-1794) was at that time Physician of the Royal Naval Hospital at Haslar. He is perhaps best known for his famous Treatise on scurvy (1753). It is ironic that Cook used Irving's method, and when the long thin tube was found to go rusty, a return to Lind's apparatus was advised (Lloyd and Coulter, 1961). Having introduced Charles Irving rather as the villain of the piece, let us trace the steps by which this young surgeon of the Arrogant came to win a Parliamentary prize of $\mathfrak{\$ 5 , 0 0 0}$ in. 1772 for this "invention", which he effectively demonstrated in person during the 1773 voyage, aboard the Racehorse, with Phipps.

The report reluctantly, yet so unselfishly, signed by Lind is much repeated in later documentation, so that it seems proper to transcribe it here in full: 113

We whose names are hereunto subscribed have carefully examined $\mathrm{Mr}$ Irving's method of rendering sea water fresh by distillation and do certify that eighty gallons of sea water did in twenty five minutes after being put into the Arrogant's copper and a fire made, distill in the proportion of twelve gallons per hour into fresh water, perfectly well tasted and of less specific gravity than the best spring water in the neighbourhood. It completely dissolves soap and affords no precipitation by adding a solution of silver in aquafortis. Mr Irving's apparatus consists of a single tube between seven and eight feet long, which may be easily made on board the ship, of tin or thin iron plates, and the distillation carried on without inconvenience to the business of the ship.

We further declare to the best of our judgement that this method is founded upon a principal in distillation, new, and hitherto not practised and which we believe will afford great advantage to that art in general, as well as fully answer the end proposed of supplying ships with a suf- 
ficient quantity of sweet wholesome water, and not to be distinguished from the best spring water after being a short time exposed to the air.

Mr Irving has also communicated to us the whole of his process which appears to depend on such simple and evident principles that we apprehend the most ordinary capacity sufficient to carry it into execution on board any ship or vessel whatever.

Every ships boiler or copper tho' deemed as two, is in fact but one large vessel, with a partition nearly in the middle; and altho' only one part or boiler is in use at the time when pease or oatmeal are dressed, yet water must be kept in the other to preserve its bottom. This latter circumstance $\mathrm{Mr}$ Irving takes advantage of, and has actually drawn off sixty gallons of fresh water during the boiling of either of the above mentioned provisions and be a strict examination of the cook and his assistants no additional fuel was used.

But in cases of great sickness or where there is an absolute necessity of a greater expence of water than usual, Mr Irving can by employing both coppers distill five hundred gallons of water in the space of twenty-four hours, and that with the same quantity of fuel in proportion to the time as is required in the ordinary business of the ship; and we are clearly of opinion that by an inconsiderable alteration of setting the navy coppers, at a very small expence according to a plan shown us by Mr Irving there will be a considerable saving of fuel, without any inconvenience whatever.

$\begin{array}{lll}\text { Physician at the hospital.... } & \begin{array}{l}\text { James Lind } \\ \text { John Laforey } \\ \text { James Hackeson } \\ \text { David Ramsay Karr } \\ \text { John Cowcher } \\ \text { Thomas Weir }\end{array} & \begin{array}{l}\text { Captain } \\ \text { Master }\end{array} \\ \text { Surgeon of the yard... } & \begin{array}{l}\text { Chymist } \\ \text { Surgeon }\end{array}\end{array}$

In November 1771, Lord Sandwich sent two bottles of water distilled by Dr. Irving from sea water to Dr. Richard Watson, Bishop of Llandaff and author of Chemical essays (1782). The latter's experiments showed that the distilled water was "not wholly free from saline particles; but it probably contains them in so small a proportion, as not to injure its salubrity to any sensible degree" (Watson, 1782: Vol.2:171-172).

On 28 February 1772 , King George III recommended a petition by Irving for the consideration of the House of Commons. This petition proclaimed the "national benefit" of his apparatus, "fully proved, as well by ... experiments as by frequent practice in the course of a long voyage". Irving was said to have "relinquished all other pursuits" to make his device practicable and to introduce it into general use, thereby impairing "his own private fortune". The House was requested by him "to grant such public reward to the petitioner for this discovery as the importance thereof shall deserve'".14 The matter was referred to a committee, Sir George Colebrooke, Lord Howe, and others, ${ }^{115}$ who reported to the House on 6 April 1772, two other petitions meanwhile having also been received. ${ }^{116}$ Reference was made to a previous payment of $£ 500$ by the Admiralty to one Hoffman for his process in 1765. The Arrogant report on Irving's apparatus was read, as well as that by the surgeons of the Northumberland, the Tartar, the Bellona, the Prince of Wales, and the Centaur. A number of surgeons and captains had been examined by the committee, all of whom had spoken favourably. On a voyage of five months to the Falkland Islands, for instance, in 1771, Captain John Stott of H.M.S. Juno had used Irving's method all the time, finding the process "easy and done while the beef or anything is boiling" without any additional consumption of fuel or "incumbrance or inconvenience on board ship". He distilled for three hours daily and produced 9-10 gallons per hour, using one ship's copper. He found the water purer than any other, mixing "better with grogg" and being much preferred by the officers and crew. The apparatus was fixed "as easily as you can put the cover on the copper". The water distilled from the sea water in which beef, pork, pease, and oatmeal were boiling was always fresh and good, although it partook of the taste of the food. Further support came from the Secretary of the Admiralty, who informed the Committee that Irving's apparatus had been put on board all ships lately sent to the East Indies, while another Member stated that it was in all H.M. Ships recently sent out.
The many voices in favour of Irving and his apparatus drowned those in favour of the other petitioners, Daniel Scott and Bartholomew Dominicetti, M.D. It was resolved by the House on 11 May 1772 "that a sum not exceeding five thousand pounds be granted to His Majesty, to be paid to Charles Irving for the discovery of an easy and practicable method of making sea water fresh and wholesome". 117

Lind, as we have seen, said nothing. Not so the French, who considered Irving's apparatus merely to be a copy of Poissonnier's, in use nine years earlier. ${ }^{118}$ Phipps appears also to have been one of the sceptics. When speaking in Parliament on 9 February 1773 in favour of a petition from the Captains of the Navy for an increase in pay, he is reported to have remarked that much larger sums had been granted for perhaps less honourable purposes and that only the previous session "one gentleman had half the proposed addition voted him, for an improvement only in the method of making salt water fresh". 119

\section{APPENDIX C}

\section{NOTE ON PLACE-NAMES IN THE TEXT}

A list of Svalbard place-names from the preceding text follows below, with their modern Norwegian equivalents, kindly provided by Mrs Sylvia Gethin of the Scott Polar Research Institute, Cambridge. It will be seen that at least two of those resulting from the 1773 expedition survive today.

\section{Prince Charles Island Magdalena Hook Hakluyt's Headland \\ Dane's Gat \\ Fair Haven \\ Cloven Cliff \\ Vogel Sang \\ Outer Norway \\ Deadman's Island \\ Marble Island}

Moffen Island
Hinlopen Straits
North East Land
Low Island
Seven Islands
Phipps Island
Walden's Island
Smeerenberg
Amsterdam Island

Moffen Island

Hinlopen Straits

North East Land

Seven Islands

Phipps Island

Smeerenberg

Amsterdam Island

\section{Prins Karls Forland \\ Magdalenehuken \\ Hakluythovden \\ Danskegattet \\ Fair Haven \\ Klovningen \\ Fuglesangen \\ Ytre Norskǿya \\ Likholmen}

According to The place-names of Svalbard, Skrifter om Svalbard og Ishavet No. 80, this cannot be identified

Moffen

Hinlopenstretet

Nordaustlandet

Lågøya

Sjuøyane

Phippsoya

Walden $6 y a$

Smeerenburg

Amsterdamøya

\section{ACKNOWLEDGEMENTS}

To the Marquis of Normanby for access to the Mulgrave Papers and to Mrs. J. Mortimer in connection with these; to the Royal Society, particularly the Librarian (Mr. N. Robinson), the Archivist (Mr. L. Townsend), and Ms. S. Grover; to the late Dr. A.M. Lysaght; to the Wellcome Institute for the History of Medicine; to the Earl of Dartmouth and to the Staffordshire Record Office and William Salt Library, Stafford (particularly Mrs. D. Randall); to the Public Record Office (Dr. N.A.M. Rodger); to the British Library; to Mrs. S. Gethin of the Scott Polar Research Institute; to Miss M.B. Deacon; to Dr. A. McConnell; to Dr. Hilary Shimmin; to the Victoria and Albert Museum (Mr. L. Lambourne) and the British Museum, Department of Prints and Drawings (Mr. P. Hulton); to the British Museum, Natural History (Miss Dorothy Norman); to the Royal Society of Arts (Mr. D. Goddard); to Mrs. Jane Lovelock; to Cordelia Stamp; to Mr. Charles Leggatt; to Messrs. Turner and Rogers; to Mr. W.B. Harland and Dr. M.J. Hambrey of the Department of Earth Sciences, Cam- 
bridge University; to Norsk Polarinstitutt (Dr. Tore Gjelsrik, Director, and Mr. Knut Heggelund); to the Frick Art Reference Library (Ms. Marie Keith); to Lieut. Commander A.C.F. David, R.N. of the Hydrographic Department, Ministry of Defence; to colleagues at the National Maritime Museum (Mr. H.D. Howse, Mr. A.W.H. Pearsall, Dr. R.J.B. Knight, Mr. S. Riley, Dr. van der Merwe, Mr. P. Ince, Mr. J. Munday, Mr. H. Preston, Mr. A. Stimson, Mr. M. Dandridge, Mrs. A. Montague, Miss J. Weal, Mrs. D. Waldman, Mrs. E. Wiggans, Miss L. Macfarlane, Mr. B. Tremain and the staff of the Photographic Section); and last but not least to Dr. (later Professor) M.C. Lobban, leader of the Cambridge Physiological Expedition, 1955, who took me to Spitsbergen.

\section{NOTES}

'Quoted in Young (1976[1817]:864).

${ }^{2}$ Kerguelen-Trémarec himself had recently made two voyages to the north, in 1767 and 1768 . The formation of sea ice is discussed in his book (Kerguelen-Trémarec, 1771/1772:20-25).

${ }^{3}$ Mémoires de l'Institut National des Sciences et Arts, Sciences morales et politiques 3(9):40-60. This had been delivered in 1798 . Part two of this work was never published, and may have formed the substance of a memorandum to the Consuls in 1801, suggests MartinAllanic (1964:1538-1539, 1544). Bougainville's original notes on this topic form part of the Bougainville collection in the National Maritime Museum, Greenwich, class-mark BOG/3.

4Phipps (1774:12). Alas, d'Alembert's "short paper" drawn up with "conciseness and elegance" is not to be found in the Mulgrave papers.

sMulgrave papers, d'Alembert to Phipps, 7 September 1774.

6Mulgrave papers, Phipps to Bougainville, undated draft in French.

'Mulgrave papers, Bougainville to Phipps, 2 aoust 1774 and Phipps to Bougainville, undated draft.

'Dartmouth papers, Staffordshire County Record Office, D (W) $1778 / \mathrm{V} / 284$. In this collection, there is reference to Engel's "Secret Mémoire of June 30th 1773; graciously accepted by his Majesty with many documents", reference D (W) 1778/III/320. This was, of course, after Phipps had departed.

'For Barrington's life, see the Dictionary of National Biography, and Davies (1972:Vol.I:61-61). This last reference kindly supplied by Miss M.B. Deacon.

${ }^{10}$ Royal Society Council minutes, 1769-1782. Vol. 6:158.

"Anonymous journal of the voyage, published London: Newbery, 1774 , p. xxvi. This publication, which came out before Phipps's official narrative, seems to have been based mainly on a journal kept in the Carcass. While one can distinguish from the text those who did not write it, the "journalist" remains unknown. Perhaps the most likely person was the surgeon, William Wallis. On bomb vessels, see A.W.H. Pearsall, Polar Record (1973) 16(105):781-788.

12National Maritime Museum, ADM/B/187. Transcript by Miss K. Lindsay-MacDougall, May 1958.

${ }^{13}$ Anonymous Newbery narrative, p. xxvii-xxviii.

${ }^{14}$ Mulgrave papers, VI, 3/5 Victualling Office to Phipps, 7 May 1773. 1sBritish Library, King's 224.

${ }^{16}$ See table reproduced by Savours and Deacon, The British Arctic (Nares) Expedition of 1875-76 and its predecessors. In: Starving Sailors: Proceedings of the International Symposium on the Influence of Nutrition on Maritime History, held at Greenwich, April.1980. London, National Martime Museum, 1981.

${ }^{17}$ Anonymous Newbery narrative, p. 54.

18Mulgrave papers, VI 3/6, Navy Office to Phipps. 10 May 1773.

${ }^{19}$ Anonymous Newbery narrative, p. 31.

${ }^{20}$ Royal Society archives, Blagden letters, Phipps to Blagden, 16 September 1774.
21Phipps's name, however, does not appear among the captains in Sandwich's appointments books in the National Maritime Museum (SAN/1 and SAN/2). For Phipps's life, see also the Dictionary of National Biography, the biography in George Young (1976[1817]: 863-866), and the Naval Chronicle (1802) Vol. 8:89-110.

${ }^{22}$ National Maritime Museum, ADM/B/187. Transcript by Miss K. Lindsay-MacDougall, May 1958.

${ }^{23}$ Public Record Office, ADM/36/7490 and ADM 36/7567.

${ }_{24}^{24}$ Public Record Office, ADM/2/98.

2sPublic Record Office, ADM/2/98.

26Public Record Office, ADM/2/98.

${ }^{27}$ Royal Society Council minutes, 1769-1782. Vol. 6:172.

${ }^{28} \mathrm{Also}$ see Man is not lost: a record of two hundred years of astronomical navigation with the 'Nautical Almanac' 1767-1967. London, HMSO, 1968.

${ }^{29}$ Four of Harrison's timekeepers, $\mathrm{H} 1, \mathrm{H} 2, \mathrm{H3}$, and $\mathrm{H} 4$ belong to the M.O.D. Hydrographic Department and are at present exhibited at the National Maritime Museum. The fifth, owned by the Worshipful Company of Clockmakers, is in the Guildhall. See Gould (1923) and Howse (1980).

30Public Record Office, ADM/2/98.

${ }^{3}$ For Lyons, see the Dictionary of National Biography and the Confirmed minutes of the Board of Longitude, Vol. 5, at the Royal Greenwich Observatory, Herstmonceux, Sussex, of which minutes there are bound photocopies, as well as copies of other Board of Longitude records in the Old Royal Observatory, National Maritime Museum, Greenwich.

${ }^{32}$ Mulgrave papers, VI 3/31.

${ }^{33}$ Note by the writer's colleague, Mr. Peter Ince. See also Phipps (1774:94, table), Bouguer (1753:Ch.3:95-110), and May (1973: 113-114). There is an entry for Bouguer in Michaud (1815).

${ }^{34}$ Presumably the surgeon, anatomist, and writer (1728-1793).

${ }^{35}$ Thordarson Collection, University of Wisconsin, fully transcribed in Lysaght (1971:256).

${ }^{36}$ Smith's wording reproduces that of the Gentleman's Magazine, Vol. 43, Historical Chronicle of 12 March 1773, p. 197.

${ }^{37}$ Kentish Gazette, 20-24 March 1773.

38Referred to in Smith's (1911:36) footnote, and now in the Dixon Library Sydney. The transcript by Sarah Sophia Banks, dated 1773, is in the Wellcome Institute for the History of Medicine, London, to which I was kindly referred by Dr. Lysaght.

${ }^{39}$ British Museum (Natural History), Botany Library, Banks Collection, Dawson Turner Copies, Vol. 1:51-53; transcript kindly passed to me by Cordelia Stamp.

${ }^{40}$ Royal Society Council minutes, 1769-1782. Vol. 6:172.

${ }^{41}$ A similar entry praising Sandwich occurs in Cook's journal kept in the Resolution, 2 May 1772. See J.C. Beaglehole (1955-1968: Vol.2:5).

${ }^{42}$ Public Record Office, ADM/51/757 and ADM/51/167.

43Public Record Office,ADM/2301/P.

44Public Record Office, ADM/51/167. This instrument does not feature in Lyons's paper on the astronomical observations and timekeepers in Appendix to Phipps's Voyage.

45Information kindly supplied by Dr. Anita McConnell. For the bottle see Phipps (1774:144) and Figure 9; for the thermometer, Philosophical Transactions (1757) 50(1):300-310.

${ }^{46}$ Anonymous Newbery narrative, p. 32. He was perhaps the third Earl of Egremont (1751-1837), of Petworth House.

${ }^{47}$ Clarke and M'Arthur, Life of Admiral Lord Nelson. London, 1810, p. 7. This is confirmed in Phipps's ms journal in the British Library, King's 224, and in his Voyage (1774:70). John Cleveley, Jr., must have worked from d'Auvergne's sketches on the return of the expedition; his work is dated 1774 and although it has been reputed that he 
accompanied Phipps, this was not so. He is not in the muster books, nor is there any reference to him in other sources. His four watercolours depicting scenes during the voyage are reproduced in this paper. See Savours (1983).

${ }^{48}$ Midshipman Thomas Floyd's journal, published in Markham (1879:95).

${ }^{49} \mathrm{~A}$ diary kept during a Greenland whaling voyage of about this time, by one George Kerr, a Scottish surgeon, survives in Aberdeen University Library. It provides a spirited first-hand account of a season with the whaling fleets in the ice off Spitsbergen and is published, edited and abridged, in Polar Record (1959) 9(63):534-546.

soPublic Record Office, ADM/51/167.

s!Public Record Office, ADM/51/167.

52The anonymous narrative calls her the Marquis of Rockingham, perhaps confusing her with the Adventure of Cook's second voyage, formerly so named.

${ }^{53}$ Anonymous Newbery narrative, p. 35.

${ }^{54}$ Anonymous Newbery narrative, p. 41.

${ }^{55}$ Anonymous Newbery narrative, p. 57.

${ }^{56}$ See Beechey (1843:310-311, 323-324), for discussion of the errors made.

57The originals, upon which these last two are based, are in the Hydrographic Department (Taunton), refs. d31/2 and W83 (copy); d31/1. Although not identical with the published versions, there are no significant differences. The original of the plan of Fair Haven is not held, unless it is an enlargement of part of $\mathrm{d} 31 / 1$. The foregoing information was kindly supplied by Lieut. Commander A.C.F. David, R.N. See also Hydrographic Department Professional Paper (1950) No. 13:62.

${ }^{58}$ Anonymous Newbery narrative, p. 56.

${ }^{59}$ Anonymous Newbery narrative, p. 44.

${ }^{60}$ Anonymous Newbery narrative, p. 44-45.

${ }^{6}$ Anonymous Newbery narrative, p. 55-56.

${ }^{62}$ Captain's $\log$ of the Racehorse, National Maritime Museum $\mathrm{ADM} / \mathrm{L} / \mathrm{R} / 1$.

${ }^{63}$ Anonymous Newbery narrative, p. 59.

${ }^{64}$ Public Record Office, ADM/51/167.

${ }^{65}$ Anonymous Newbery narrative, p. 60-63.

${ }^{66}$ James Allen, the next year master of the Endeavour, store ship; the same Endeavour of Captain Cook's first voyage. He was washed overboard from this vessel when returning from the Falkland Islands in 1774 during very severe weather. The Gentleman's Magazine of September 1774 (p. 443), in recording the arrival of the Endeavour at Portsmouth "with the garrison of Falkland's island" and stores, wrote of the late master that he was "the officer alluded to in Capt Phipps' Voyage to the North Seas, who was frightened by a bear, to the no small diversion of the boat's crew that landed with him on Moffet's island. See the story in the account of that voyage published by Newbery in which the reader will find more entertainment than in the account published by authority, though not so much nautical knowledge".

${ }^{67}$ As background to this view of landscape, see Hussey (1967); also Frost (1979).

${ }^{68}$ Identified as Phipps Island by Conway (1906:281).

${ }^{69}$ Public Record Office, ADM/51/167.

${ }^{70}$ Anonymous Newbery narrative, p. 67.

"Anonymous Newbery narrative, p. 69.

${ }^{2}$ Anonymous Newbery narrative, p. 69.

${ }^{73}$ Anonymous Newbery narrative, p. 69.

${ }^{74}$ Anonymous Newbery narrative, p. 70. Also see Savours (1983).

75Public Record Office, ADM/51/167.

${ }^{76}$ Frederick Walden of the Racehorse, born in Uppsala. Public Record Office ADM/36/7490.
${ }^{77}$ Captain's log of the Racehorse, National Maritime Museum ADM/L/R/1. Entry for 7 August.

${ }^{78}$ Anonymous Newbery narrative, p. 71.

${ }^{79}$ Comparable in polar literature with the narrative by Captain William Scoresby Jr. of a whale and her calf, and that by H.G. Ponting of a Weddell seal and her baby in The Great White South.

${ }^{80}$ Anonymous Newbery narrative, p. 74-75.

saptain's log of the Racehorse, National Maritime Museum ADM/L/R/1. Entry for 8 August.

${ }^{82}$ Anonymous Newbery narrative, p. 78.

${ }^{83}$ The Naval Chronicle of 1800 in its "Biographical memoir of the Right Honourable Nelson of the Nile" also relates the above and observes: "thus did his mind at this early period glow with fresh energy at the sight of danger".

${ }^{84}$ Anonymous Newbery narrative, p. 78-79. Baird's naval career can be briefly summarized: Lieutenant, 1757. Served in the Prince George (1758); the Prince (1759); Ester, cutter (1769); Carcass (1773); Richmond (1776); America (1778). Source: The commissioned sea officers of the Royal. Navy. National Maritime Museum, 1957. His name is entered in Lord Sandwich's appointments books (National Maritime Museum, SAN/1) as First Lieutenant of the Carcass, only recommended by himself for promotion. No entry appears in the columns headed "Case" and "How provided for". He must have lacked "Interest".

${ }^{85}$ Anonymous Newbery narrative, p. 79-80.

${ }^{86}$ Public Record Office, ADM/51/167.

${ }^{87}$ British Library, King's, 224.

${ }^{8}$ National Maritime Museum, ADM/L/R/1.

${ }^{89}$ Anonymous Newbery narrative, p. 86.

${ }^{90}$ Anonymous Newbery narrative, p. 87.

91Anonymous Newbery narrative, p. 87.

${ }^{92}$ Anonymous Newbery narrative, p. 87-88.

${ }^{93}$ Anonymous Newbery narrative, p. 88.

${ }^{94}$ Anonymous Newbery narrative, p. 89.

${ }^{95}$ Anonymous Newbery narrative, p. 89.

${ }^{96}$ Phipps (1774:70). The Oxford English Dictionary cites Phipps as first using the word "iceberg" (from the Dutch) to mean "An Arctic glacier which comes close to the coast and is seen from the sea as a hill or hummock". Dr. A. McConnell kindly pointed this out.

${ }^{97}$ Anonymous Newbery narrative, p. 92.

98 Public Record Office, ADM/51/167.

99 Gentleman's Magazine 44(1774):86.

${ }^{100}$ Gentleman's Magazine 44(1774):424.

${ }^{101}$ Mulgrave papers, VI, 3/30. D'Alembert to Phipps, 7 septembre 1774.

${ }^{102}$ Kentish Gazette, 8 October 1773.

${ }^{103}$ Voyage au Pole boréal, fait en 1773 . . .Paris, 1775 :

${ }^{104}$ Mulgrave papers, Morellet to Phipps, 20 mai 1775.

${ }^{105}$ Royal Society Archives, Blagden collection, Phipps to Blagden, 24 September 1774. There is more correspondence relating to this in the Mulgrave papers, from Dr. Charles Blagden and Israel Lyons to Phipps.

${ }^{106 R o y a l ~ S o c i e t y, ~ b o u n d ~ v o l u m e s ~ o f ~ l e t t e r s ~ a n d ~ p a p e r s, ~ V o l . ~} 6$.

${ }^{107}$ Royal Society, bound volumes of letters and papers, Vol: 6 .

${ }^{108}$ Royal Society, bound volumes of letters and papers, Vol. 6. These papers by Daines Barrington were not printed in the Philosophical Transactions of the Royal Society, but were published as pamphlets in 1775 and 1776, and later in his Miscellanies (London, 1781). After the Napoleonic Wars in 1818 when another Arctic expedition was despatched by the Admiralty, the essays were once again published, in conjunction with Colonel Mark Beaufoy, as The possibility of approaching the North Pole asserted: 
${ }^{109}$ Dartmouth Papers, Stafford: D (W) 1778, III/320. Letter from Rodney Valtravers to the Earl of Dartmouth, 30 December 1774.

${ }^{110} \mathrm{D}$ (W) $1778 / \mathrm{V} / 288$.

"'Beaglehole (1967) has traced the influence of Engel and Barrington in his introduction to Cook's third voyage.

${ }^{112}$ For Irving's method, see the account by him in Phipps (1774: 205-221, plate).

${ }^{1{ }^{13}}$ National Maritime Museum; ADM/A/2640, enclosure in a letter from the Admiralty to the Navy Board dated 23 February 1771, desiring that a number of His Majesty's ships bound for the East Indies, under the command of Rear Admiral Harland, should be fitted with the tubes under Mr. Irving's inspection. Transcript by Miss K. Lindsay MacDougall, 1958.

${ }^{14}$ House of Commons Journal, Vol. 33.

"1s House of Commons Journal, Vol. 33.

${ }^{116}$ House of Commons Journal, Vol. 33.

${ }^{11}$ House of Commons Journal, Vol. 33.

${ }^{118}$ See Baumé (1773: Vol. 3:588-589) and the entry on Poissonnier in Michaud's Biographie Universelle. The first and second versions of Poissonier's apparatus are illustrated by two plates in Baumé. There is an interesting. letter in the Gentleman's Magazine (Vol. 43:70-71 [February 1773]), also.championing Poissonnier, from an Englishman abroad - possibly the "Louis du Tens, physician Anglais" mentioned by Baumé - signed "L.D.' ' and dated Spa, 7. August 1772.

"'Gentleman's Magazine, Vol. 43 (1773):161-162. The same periodical (Vol. 42, May 1772), when reporting the award to Charles Irving, remarked that he was "the same who invented the marine chair some years ago". The present writer has pursued this reference in the Board of Longitude papers, but the trail proved a false one and the inventor one Christopher Irving.

\section{REFERENCES}

BALLEINE, G:R. 1973. The tragedy of Philippe d'Auvergne. London: Phillimore.

BAUMÉ, A. 1773. Chymie Experimentale et Raisonée. Paris.

BEAGLEHOLE, J.C. (ed.). 1955-1968. The Journals of Captain James Cook. Cambridge.

1967. The Voyage of the "Resolution". and "Discovery". Part 1. Cambridge.

BEECHEY, F.W. 1843. A voyage of discovery towards the North Pole... 1818. London.

BOUGAINVILLE, L.-A. 1801. Essai historique sur les navigations anciennes et modernes dans les hautes latitudes septentrionales: Part 1. Mémoires de l'Institut National des Sciences et Arts, Sciences morales et politiques $3(9): 40-60$.

BOUGUER, P. 1753. Nouveau traité de navigation. Livre 2 . Paris.

CHAPMAN, R.W. (ed.). 1970. Johnson's Journey to the Western Isles of Scotland and Boswell's Journal of a Tour to the Hebrides with Samuel Johnson, LLD. London: Oxford University Press.

CLARKE, J. and M:ARTHUR, J. 1810. Life of Admiral Lord Nelson. London.

CONWAY, SIR MARTIN. 1906. No Man's Land: A History of Spitsbergen. Cambridge: Cambridge University Press.

DAVIES, J.C. (ed.): 1972. Catalogue of manuscripts in the Library of the Honourable Society of the Inner Temple. London: Oxford University Press.

ENGEL, S. 1765. Mémoires et observations géographiques et critiquès sur la situation des pays septentrionaux d'Asie et d'Amérique d'après les relations les plus récentes. Lausanne. [German edition 1772].

FROST, A. 1979. New geographical perspectives and the emergence of the romantic imagination. In: Fisher, R. and Johnston, H. (eds.). Captain James Cook and his Times. Vancouver and London. 5-19.
GOULD, R.T. 1923. The Marine Chronometer: Its History and Development. London.

HOWSE, D. 1980. Greenwich Time and the Discovery of the Longitude. Oxford.

HUSSEY, C: 1967. The Picturesque, New Impression. London: Cass.

KERGUELEN-TRÉMAREC, Y.J. de. 1771/1772. Relation d'un voyage dans la mer du Nord: Paris (1771); Amsterdam and Leipzig (1772).

LLOYD, C. and COULTER, J.L.S. 1961. Medicine and the Navy. Vol. 3, 1714-1815. Edinburgh: Livingstone.

LUBBOCK, B. 1955 [1937]. The Arctic whalers. Glasgow: Brown and Ferguson.

LYSAGHT, A. 1971. Joseph Banks in Newfoundland and Labrador, 1766. London: Faber and Faber.

MARKHAM, A.H. 1879. Northward Ho! London.

MARTIN-ALLANIC. 1964. Bougainville; navigateur et les découvertes de son temps. Paris.

MAY, W.E. 1973. A History of Marine Navigation. Henley-on-Thames.

MICHAUD. 1815. Biographie Universelle. Paris.

PENNANT, T.M. MS. Outlines of the globe. Vol. 2. Northern regions. National Maritime Museum, MS P16/2.

PHIPPS, C.J. 1774. A Voyage towards the North Pole undertaken by His Majesty's command, 1773. London: Nourse.

RICH, E.E. 1960, 1961. Hudson's Bay Company. London (1960) and New York (1961).

SAVOURS (SHIRLEY), A. 1983. The younger Cleveley and the Arctic 1773-4. The Mariner's Mirror 69(3):301-304.

SMITH, E. 1911. The Life of Sir Joseph Banks. London: Bodley Head.

WATSON, R. 1782. Chemical Essays.

WILliAMS, G. 1962. The British Search for the Northwest Passage in the Eighteenth Century. London: Longmans for the Royal Commonwealth Society.

YOUNG, G. 1976 [1817]: History of Whitby. Whitby: Caedmon of Whitby Press. (Reprint). 